\title{
REE Characteristics of Lower Cretaceous Limestone Succession in Gümüşhane, NE Turkey: Implications for Ocean Paleoredox Conditions and Diagenetic Alteration
}

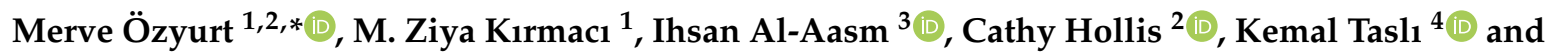 \\ Raif Kandemir 5 \\ 1 Department of Geological Engineering, Karadeniz Technical University, 61080 Trabzon, Turkey; \\ kirmaci@ktu.edu.tr \\ 2 School of Earth and Environmental Science, University of Manchester, Manchester M13 9PL, UK; \\ Cathy.Hollis@manchester.ac.uk \\ 3 School of the Environment, University of Windsor, Windsor, ON N9B 3P4, Canada; alaasm@uwindsor.ca \\ 4 Department of Geological Engineering, Mersin University, 33343 Mersin, Turkey; ktasli@mersin.edu.tr \\ 5 Department of Geological Engineering, Recep Tayyip Erdoğan University, 53100 Rize, Turkey; \\ raif.kandemir@erdogan.edu.tr \\ * Correspondence: merveyildiz@ktu.edu.tr
}

Received: 2 July 2020; Accepted: 22 July 2020; Published: 30 July 2020

\begin{abstract}
Trace and rare earth elements (REEs) are considered to be reliable indicators of chemical processes for the evolution of carbonate systems. One of the best examples of ancient carbonate successions (Berdiga Formation) is widely exposed in NE Turkey. The Lower Cretaceous limestone succession of Berdiga Formation may provide a case study that reveals the effect of ocean paleoredox conditions on diagenetic alteration. Measurement of major, trace and REEs was carried out on the Lower Cretaceous limestones of the Berdiga Formation, to reveal proxies for paleoredox conditions and early diagenetic controls on their geochemistry. Studied micritic limestone microfacies (MF-1 to MF-3) indicate deposition in the inner platform to a deep shelf or continental slope paleoenvironment during the Hauterivian-Albian. The studied limestone samples mainly exhibit low Mg-calcite characteristics with the general chemical formula of $\mathrm{Ca}_{98.35-99.34} \mathrm{Mg}_{0.66-1.65}\left(\mathrm{CO}_{3}\right)$. They are mostly represented by a diagnostic REE seawater signature including (1) slight LREE depletion relative to the HREEs (ave. 0.72 of $\mathrm{Nd} / \mathrm{Yb}_{\mathrm{N}}$ and ave. 0.73 of $\left.\mathrm{Pr} / \mathrm{Yb}_{\mathrm{N}}\right),(2)$ negative Ce anomalies $\left(\mathrm{Ce} / \mathrm{Ce} \mathrm{e}^{*}=0.38-0.81\right.$; ave. 0.57), (3) positive La anomaly $\left(\mathrm{La} / \mathrm{La}^{*}=0.21-3.02\right.$; ave. 1.75) and (4) superchondritic $\mathrm{Y} / \mathrm{Ho}$ (ave. 46.26). Studied micritic limestones have predominantly low $\mathrm{Hf}$ (bdl to $0.5 \mu \mathrm{g} / \mathrm{g}$ ), Sc (bdl to $2 \mu \mathrm{g} / \mathrm{g}$ ) Th (bdl to $0.9 \mu \mathrm{g} / \mathrm{g}$ ) contents suggesting negligible to minor shale contamination. These findings imply that micritic limestones faithfully record chemical signals of their parental and diagenetic fluids. The succession also exhibits high ratios of $\mathrm{Eu} / \mathrm{Eu}^{*}$ (1.01-1.65; ave. 1.29 corresponding to the positive Eu anomalies), $\mathrm{Sm} / \mathrm{Yb}$ (1.26-2.74; ave. 1.68) and $\mathrm{La} / \mathrm{Yb}$ ratios (0.68-1.35; ave. 0.9) compared to modern seawater and wide range of $\mathrm{Y} / \mathrm{Ho}$ ratios (29.33-70.00; ave. 46.26) which are between seawater and hydrogenetic Fe-Mn crusts. Several lines of geochemical evidence suggest water-rock interaction between parental seawater and basaltic rocks at elevated temperatures triggered by hydrothermal activity associated with Early Cretaceous basaltic magma generation. The range of $\mathrm{Ce} / \mathrm{Ce}^{*}$ values is suggestive of mostly oxic to dysoxic paleoceanographic conditions, with a sudden change to dysoxic conditions $\left(\mathrm{Ce} / \mathrm{Ce}^{*}=0.71-0.81\right)$, in the uppermost part of the MF-1. This is followed by an abrupt deepening paleoenvironment with a relative increase in the oxic state of the seawater and deposition of deeper water sediments (MF-2 and MF-3) above a sharp transition. The differences in microfacies characteristics and foraminifera assemblage between MF-1 and overlying facies (MF-2 and MF-3) may also confirm the change in paleoceanographic conditions. Therefore, REEs data obtained from studied
\end{abstract}


limestones have the potential to contribute important information as to regional paleoceanographic conditions of Tethys during an important period in Earth history.

Keywords: platform carbonates; REE + Y chemistry; paleoceanographic proxies; diagenetic proxies; NE Turkey

\section{Introduction}

The rare earth element and $Y(R E E+Y)$ signature of carbonates have been widely used to reconstruct the paleoenvironmental history of seawater in deep time [1-6]. REE $+Y$ have similar coherent chemical properties in the marine system and exhibit systematic changes in the chemical properties across the REE ( $\mathrm{La}$ to $\mathrm{Lu}$ ) series due to the progressive filling of the f-electron shell [7-13]. This causes different fractionations of Lantonides in natural systems; heavier REEs (HREE, from Ho to $\mathrm{Lu}$ ) tend to be preferentially complexed, while lighter REEs (LREE, from La to Nd) are preferentially scavenged by particles [13]. Further, the rare earth elements (REEs) occur in the trivalent state in seawater with the exception of multiple oxidation states for $\mathrm{Ce}$ and $\mathrm{Eu}$ [13]. Ce $\left(\mathrm{Ce}^{3+}, \mathrm{Ce}^{4+}\right)$ and $\mathrm{Eu}\left(\mathrm{Eu}^{2+}, \mathrm{Eu}^{3+}\right)$ are redox-sensitive elements, and they show distinct geochemical behaviour compared to other Lantonides [13,14]. $\mathrm{Ce}\left(\mathrm{Ce}^{3+}, \mathrm{Ce}^{4+}\right)$ and $\mathrm{Eu}\left(\mathrm{Eu}^{2+}, \mathrm{Eu}^{3+}\right)$ are generally considered a natural proxy for revealing interaction processes between particles and solutions, and redox reactions [15-18]. These geochemical features allow carbonate sedimentologists to reconstruct ancient environmental conditions [19-22].

The Upper Jurassic-Lower Cretaceous Berdiga Formation, which consists dominantly of platform carbonates are widely exposed in the Eastern Pontides, NE Turkey. This carbonate succession is one of the best-preserved examples of ancient shallow marine environmental systems in the passive continental margin of Laurasia [23]. The carbonate succession is well defined in terms of its stratigraphical and sedimentological characteristics [23-37]. Sediments are platform carbonates which are represented by varying lithofacies ranging from supratidal to continental slope [23,27-33,38]. The platform carbonates have undergone multiple stages of diagenesis, including dolomitization and recrystallisation $[23,31-34,39]$. Dolomitization was interpreted to have been initiated by seawater and/or partly modified seawater prior to compaction during shallow-moderate burial, and massive dolomite bodies were then continuously recrystallised by the circulation of episodic diagenetic fluids with elevated temperatures during deeper burial [31]. The recrystallisation processes have been related to widespread Late Cretaceous to Cenozoic magma generation [23,31-33].

Although the diagenetic history seems complex, the mechanisms and origins of dolomitization have been well described in recent studies [31]. However, there has not been an attempt to investigate the micritic limestone strata that are least diagenetically altered and should, therefore, provide proxies for paleoredox conditions and early diagenetic controls on their geochemistry. Consequently, this study focuses on the limestone strata outcropping in the Mescitli area in the southern part of Eastern Pontide (NE Turkey). Here, we present a petrographic analysis coupled with REE+Y characterisation of the limestone succession. The main purpose of the current study is (1) to determine ancient seawater composition using marine carbonates of NE Turkey, from inner platform to slope paleoenvironments; (2) to define the redox conditions and discuss the paleoceanographic proxies and (3) to discuss the role of potential diagenetic influence on REE signals of ancient carbonates.

\section{Geological Setting}

Turkey comprises a series of tectonic units, which are separated by ophiolitic suture zones [40,41]. The Sakarya Zone consists of east-west trending Alpine continental fragments along with northern Turkey and is generally known as the Eastern Pontides, constituting a significant part of the Alpine-Himalayan system. Magmatic, metamorphic and sedimentary Mesozoic to Cenozoic rocks 
are widely exposed in Eastern Pontide (e.g., [40,41]), and a well-constrained tectono-magmatic and stratigraphic framework has been established (Figure 1). Eastern Pontide can roughly be separated into two main subzones based on its dominant lithological differences from north to south [40-42] (Figure 1). The northern subzone is mainly characterized by Late Mesozoic and Early Cenozoic magmatic rocks [42-49], while the southern subzone is predominantly characterized by Jurassic carbonate and clastic sedimentary rocks [50-54].

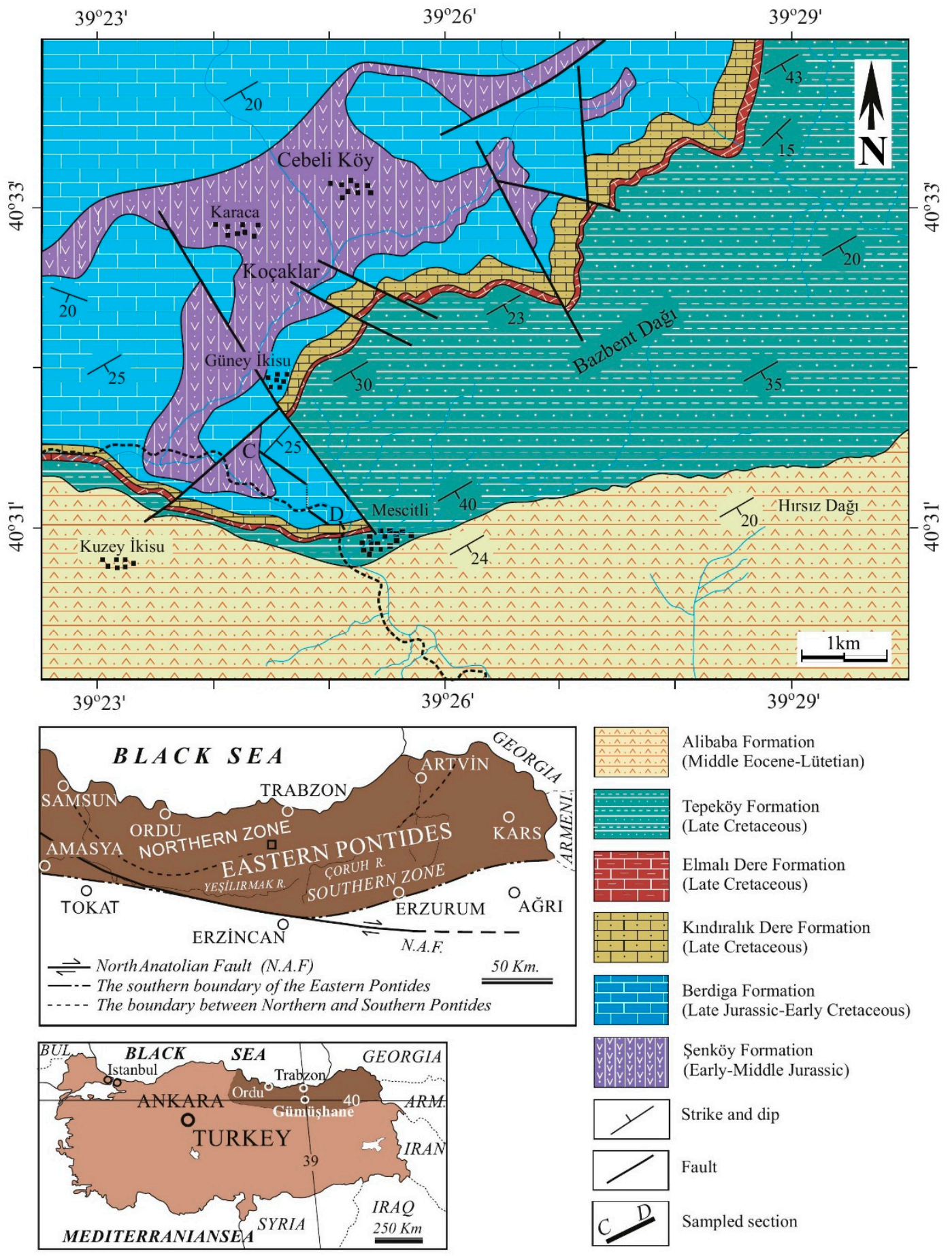

Figure 1. Location and simplified geological map of the Mescitli area [54].

The Mescitli Area (Gümüşhane, NE Turkey) is located in the southern part of the Eastern Pontide, where Upper Jurassic-Lower Cretaceous carbonates are well exposed (Figure 1). In the southern 
part, the Hercynian basement mainly constitutes a metamorphic unit dated as $320.3 \pm 1.7 \mathrm{Ma}$ [55] and Upper Carboniferous Gümüşhane granitoid [56,57]. These basement rocks are generally overlain by the Lower to Middle Jurassic volcano-sedimentary successions consisting mainly of siliciclastics, basalt-andesite and associated volcanoclastic, deposited within an extensional (rift) basin, and rarely Ammonitico-Rosso limestone facies [58,59]. Upper Jurassic to Lower Cretaceous carbonate successions (Berdiga Formation) [35] lie conformably over the volcano-sedimentary successions. Based on benthic foraminiferal assemblages, the platform carbonates in the Eastern Pontides are of Oxfordian to Albian age [27-29,35-37]. In the Mescitli Area, the lower part of the Berdiga Formation is completely dolomitized [31] while the upper part comprises a well-preserved limestone succession which is the focus of this study. The succession is overlain by an Upper Cretaceous unit which comprises three different sedimentary assemblages: (1) yellowish coloured, sandy limestones, (2) globotruncanid-bearing-red pelagic limestones and (3) siliciclastics locally with interbedded felsic tuff [40,53,54,60,61]. Both Hercynian basement and post-Hercynian volcano-sedimentary associations are cut by Eocene granitic intrusions and unconformably overlain by the Early Cenozoic volcano-sedimentary sequence $[44,46,62,63]$.

\section{Studied Section}

The studied Upper Jurassic Lower Cretaceous carbonate successions are widely exposed in the southern part of Eastern Pontides [23,27-39]. The succession is generally composed of platform carbonates, and their lithofacies reflects lateral and vertical changes in the environment from a supratidal to a continental slope facies [23,27-39]. This study is based upon the carbonate succession located in the Mescitli area of the Eastern Pontides (Figures 1, 2 and $3 \mathrm{a}-\mathrm{c}$ ). Here, the succession is estimated to be up to $400 \mathrm{~m}$ thick [31,38] and is subdivided into two informal lithological units/intervals based on the vertical change in macro-facies and microfacies characteristics [31] (Figure 2).

At the base, a $150 \mathrm{~m}$ thick-dolomite lithofacies overlies the basaltic rocks of Early to Middle Jurassic volcano-sedimentary successions (Figure 3a). The dolostones are light grey to grey coloured, thick to medium bedded $(30-50 \mathrm{~cm})$ and locally massive (Figure 3a). The middle and upper parts comprise approximately $230 \mathrm{~m}$ thick limestone succession which does not display significant diagenetic alteration petrographically, and hence primary microfacies textures are well preserved (Figures 2, $3 \mathrm{a}-\mathrm{c}$ and 4a-i), namely: (1) Benthic foraminiferal packstone microfacies (MF-1), (2) Reworked skeletal grainstone/packstone microfacies (MF-2) and (3) Sponge spicule wackestone/mudstone microfacies (MF-3) $[31,38]$. Of these, the benthic foraminiferal packstone microfacies (M-1) forms the basal part of the limestone succession. It is nearly $70 \mathrm{~m}$ thick, grey to dark grey coloured, thick to medium bedded (0.5-1.5 m) and locally massive (Figure 2). It includes Pseudolituonella gavonensis Foury, 1968, Arenobulimina spp., Praechrysalidina sp., Miliolidae and Textularidae. The presence of Pseudolituonella gavonensis, Arenobulimina spp., Praechrysalidina sp. suggest a Hauterivian-Aptian age [31,38]. The high abundance of benthic foraminifera assemblages and a relative absence of deep-water bioclasts implies deposition in an inner platform paleoenvironment.

Reworked skeletal grainstone/packstone microfacies (MF-2) conformably overly the benthic foraminiferal packstone microfacies (MF-1) and comprise approximately $80 \mathrm{~m}$ thick, light grey to grey coloured, thick to medium bedded $(25-75 \mathrm{~cm}$ ) limestones (Figure $3 \mathrm{~b})$. The predominant carbonate components are diverse, fragmented skeletal assemblage (echinoids, pelecypoda, brachiopoda (punctate shells), thin-shelled ostracoda, bryozoa) and peloids. Most of the biotic components are broken and reworked, except for small benthic foraminifera [64]. Rare plagioclase and basaltic extraclasts are observed in the base of the microfacies. The absence of a diverse and abundant benthic foraminiferal community and the fragmented assemblage of heterotrophic skeletal fragments implies that the deposition of MF-2 took place in a deeper water environment than MF-1 [31,38]. 


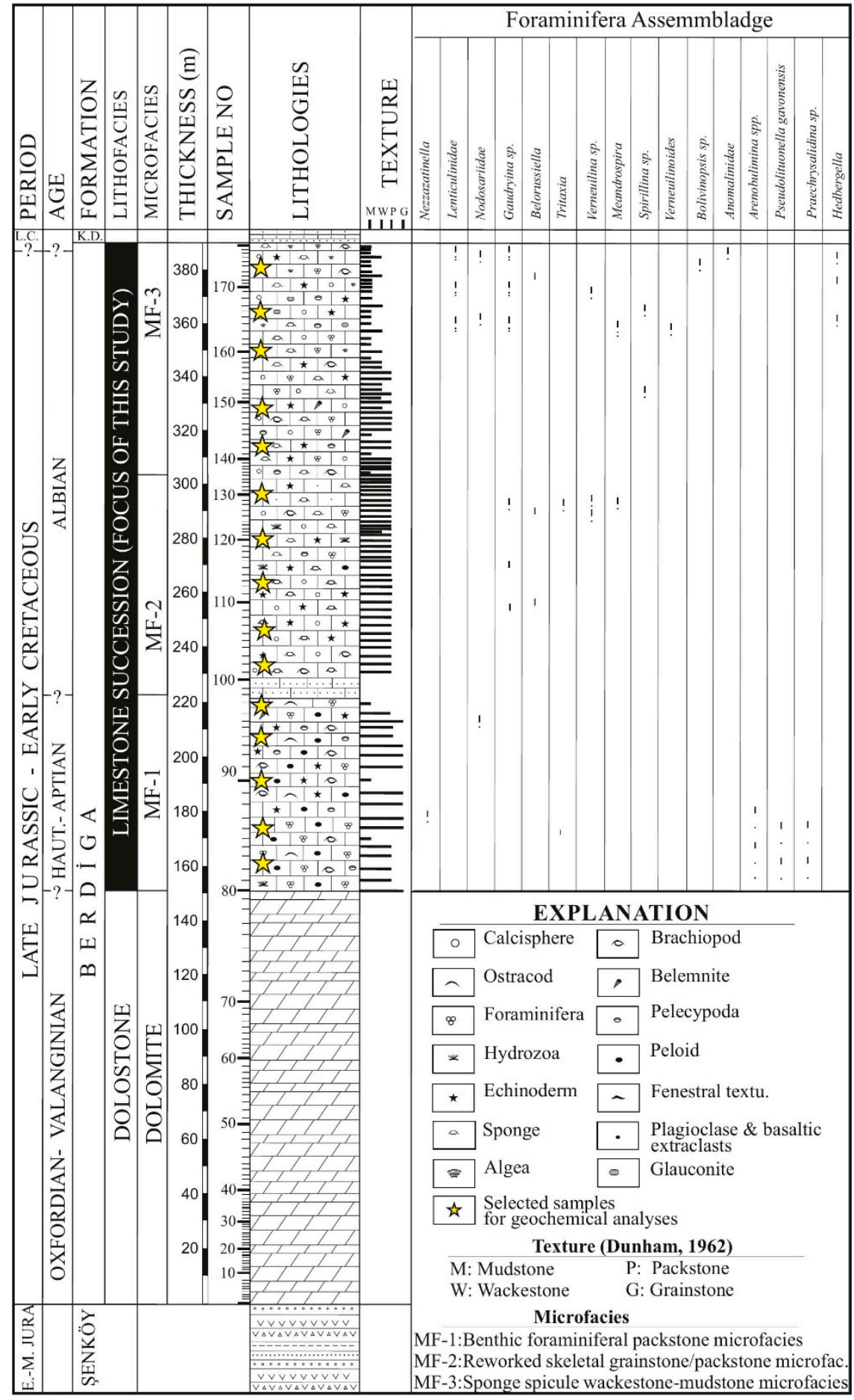

Figure 2. Stratigraphy, lithofacies and foraminifera distribution in the Berdiga Formation of the Mescitli (Gümüşhane, NE Turkey) [31,38].

Sponge spicule wackestone/mudstone microfacies (MF-3) constitute most of the upper part of the studied succession (Berdiga Formation). The contact between microfacies MF-2 and MF-3 is a gradual facies change. MF-3 microfacies comprises approximately $180 \mathrm{~m}$ thick, grey to dark grey mudstone and wackestone that is mostly characterized by sponge spicules and glauconite. The other carbonate components are allochthonous benthic foraminifera, intraclasts and rarely peloids. Besides, rare small benthic foraminifera assemblage including Lenticulinidae, Nodosariidae, Gaudryina sp., Verneuilina sp., Bolivinopsis sp., Spirillina sp. are also observed in the lower part of the lithofacies. The abundance and 
size of allochthonous skeletal fragments gradually decrease throughout MF-3 whilst the proportion of micrite increases upward. Planktonic foraminifera, including Microhedbergella, are also observed in the most upper part of the MF-3. The mud-rich texture and decrease in abundance/size of allochthonous skeletal fragments indicate that the depositional environment was deeper than the MF-2. Overall, the assemblage and the presence of the planktonic foraminifera may suggest that this was the deepest part of the succession, corresponding to a deep shelf or slope. This is consistent with coeval carbonate succession, which is reported in the Başoba Yayla area (Trabzon, NE Turkey) [34,37]. It has also been noted that the age of the most upper part of the formation is the Albian owing to the presence of Microhedbergella rischi Moullade, 1974 [65]. Therefore, it can be inferred that the age of MF-2 and MF-3 is likely Albian [31,38].

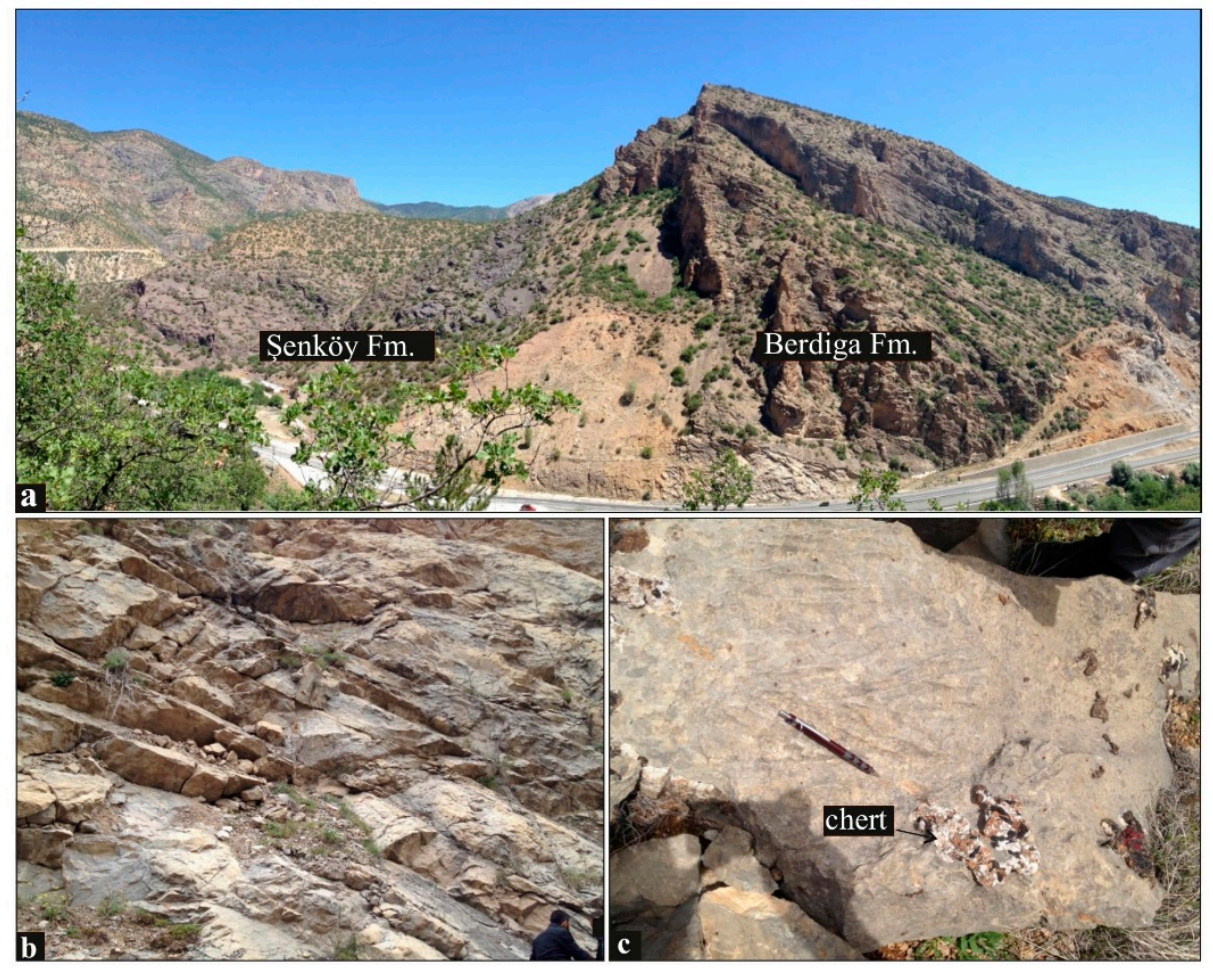

Figure 3. General lithological and macro-micro sedimentological features of the inner platform to slope environment in the interval of the Berdiga Formation (Hauterivian-Albian). (a). Field view of the Mescitli stratigraphic section; (b) thick to medium bedded Limestone (MF-1); (c) limestone with chert (MF-2 and MF-3).

\section{Material and Methods}

Upper Jurassic-Lower Cretaceous carbonates are well exposed along the Mescitli section (Figures 1 and $3 \mathrm{a}-\mathrm{c})$. The study area is situated in Mescitli-İkisu (40.528656, 39.380240), nearly $10 \mathrm{~km}$ north-west of Gümüşhane (NE Turkey). The $230 \mathrm{~m}$ of Upper Jurassic to Lower Cretaceous neritic micritic limestone of the Berdiga Formation was examined and sampled, and 100 rock samples were collected with a 20 to $50 \mathrm{~cm}$ spacing. A total of 80 samples of the Mescitli section were petrographically analyzed. Microfacies types were described based on fundamental principles of limestone classification and microfacies concept [66,67].

Representative samples from the different microfacies (Figures 2, 3a-c and $4 a-i$ ) were selected for geochemical analysis (Table 1). Selected samples are all micritic limestones (MF-1 to MF-3) not exhibiting petrographic evidence of significant post-depositional alteration such as recrystallization. Representative thin sections and a mirror-image slab of each thin section were polished to evaluate (i) weathering (ii) presence of clay minerals or basalt extraclasts (iii) micro-fissures filled with calcites or clastic components and (iv) fracturing, all of which were avoided during geochemical sampling. 
The micritic orthochemical carbonate particles corresponding to the matrix micrite of each polished slab were sampled by micro-drilling using a hand drill.

Major, minor and trace elements, including REE of selected matrix micrite of each sample, were carried out by ACME Analytical Laboratories, Ltd. (Vancouver, BC, Canada). The major elements, trace elements, and REEs in the carbonates were determined by inductively coupled plasma-mass spectrometry (ICP-MS). Analyses used $\sim 0.2 \mathrm{~g}$ of powdered sample digested in $10 \mathrm{~mL} 8 \mathrm{~N} \mathrm{HNO}_{3}$, of which $1 \mathrm{~mL}$ was diluted with $8.8 \mathrm{~mL}$ deionised water, and $0.1 \mathrm{~mL} \mathrm{HNO}_{3}$. To monitor the precision and accuracy, $1 \mathrm{~mL}$ of an internal standard (including Bi, Sc, and In) was added to the solution. For more details of these methods, please see the website of http://acmelab.com. Detection limit (dtl) of $\mathrm{CaCO}_{3}, \mathrm{MgCO}_{3}, \mathrm{SiO}_{2}, \mathrm{Al}_{2} \mathrm{O}_{3}, \mathrm{Na}_{2} \mathrm{O}, \mathrm{K}_{2} \mathrm{O}, \mathrm{TiO}_{2}, \mathrm{P}_{2} \mathrm{O}_{5}, \mathrm{MnO}$ is 0.01 wt \% with exception of $\mathrm{Fe}_{2} \mathrm{O}_{3}$ $(\mathrm{dtl}=0.04 \mathrm{wt} \%)$ and $\mathrm{Cr}_{2} \mathrm{O}_{3}(\mathrm{dtl}=0.002 \mathrm{wt} \%)$. Detection limits for Ba, $\mathrm{Ni}$ and Sc, are 1, 20 and $1 \mu \mathrm{g} / \mathrm{g}$, respectively. Detection limits for $\mathrm{Hf}, \mathrm{Zr}, \mathrm{Y}, \mathrm{La}, \mathrm{Ce}$ are $0.1 \mu \mathrm{g} / \mathrm{g}$. Detection limits for Th and $\mathrm{Nd}$ are 0.2 and $0.3 \mu \mathrm{g} / \mathrm{g}$, respectively. Detection limits for $\mathrm{Tm}, \mathrm{Tb}, \mathrm{Lu}$ are $0.01 \mu \mathrm{g} / \mathrm{g}$; for $\mathrm{Pr}$, Eu and Hu are $0.02 \mu \mathrm{g} / \mathrm{g}$; for $\mathrm{Er}$ is $0.03 \mu \mathrm{g} / \mathrm{g}$; for $\mathrm{Sm}, \mathrm{Gd}$, Dy and $\mathrm{Yb}$ are $0.05 \mu \mathrm{g} / \mathrm{g}$.

The measured REEs data of all micritic limestone samples were normalized to those of post-Archean Australian Shale (PAAS) which are previously reported (e.g., [68]). The equations of (i) $\mathrm{Eu} / \mathrm{Eu}^{*}$ ratio $=\mathrm{Eu}_{\mathrm{N}} /\left(\mathrm{Sm}_{\mathrm{N}}+\mathrm{Gd}_{\mathrm{N}}\right) 0.5$, (ii) $\operatorname{Pr}$ anomaly $=\operatorname{Pr} / \operatorname{Pr}^{*}=\operatorname{Pr}_{\mathrm{N}} /\left(0.5 \mathrm{Ce}_{\mathrm{N}}+0.5 \mathrm{Nd}_{\mathrm{N}}\right)$, (iii) $\mathrm{La}$ anomaly $=\mathrm{La} / \mathrm{La}^{*}=\mathrm{La}_{\mathrm{N}} /\left(3 \mathrm{Pr}_{\mathrm{N}}-2 \mathrm{Nd}_{\mathrm{N}}\right)$, and (iv) Ce anomaly $=\mathrm{Ce} / \mathrm{Ce}^{*}=3 \mathrm{Ce}_{\mathrm{N}} /\left(2 \mathrm{La}_{\mathrm{N}}+\mathrm{Nd}_{\mathrm{N}}\right)$ are used to express $\mathrm{Eu}, \mathrm{Pr}, \mathrm{La}$ and Ce anomalies in the studied limestones $[69,70]$.

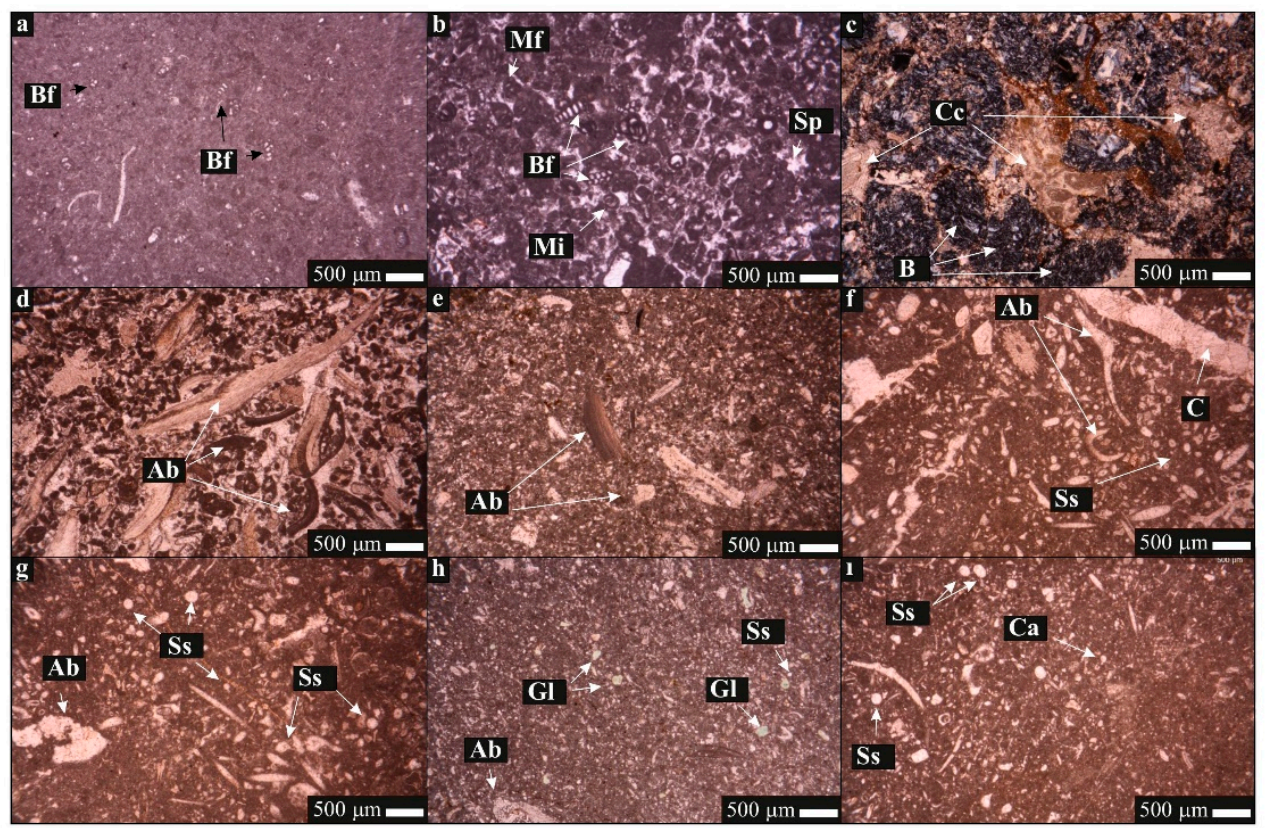

Figure 4. Benthic foraminiferal packstone microfacies (MF-1) (a,b). The transition zone between MF-1 and MF-2, showing basalt extraclasts and carbonate components (c). Reworked skeletal grainstone/packstone microfacies (MF-2) (d-f). Sponge spicule wackestone-mudstone microfacies (MF-3) (g-i). Bf: benthic foraminifera, Mf: micritized foraminifera, Mi: miliolid, Sp: sparite, Cc: carbonate component, B: basalt extraclast, Ab: allochthonous bioclasts, Ss: Sponge spicule, Gl: Glauconite, Ca: Calcisphere. 
Table 1. Major, trace and rare earth elements of the limestone succession from the Mescitli area (NE Turkey).

\begin{tabular}{|c|c|c|c|c|c|c|c|c|c|c|c|c|c|c|c|}
\hline & 1 & 2 & 3 & 4 & 5 & 6 & 7 & 8 & 9 & 10 & 11 & 12 & 13 & 14 & 15 \\
\hline Sample No & M-82 & M-83 & M-84 & M-85 & M-89 & M-91 & M-92 & M-94 & M-106 & M-110 & M-112 & M-116 & M-137 & M-141 & M-146 \\
\hline Analyte & Rock Pulp & Rock Pulp & Rock Pulp & Rock Pulp & Rock Pulp & Rock Pulp & Rock Pulp & Rock Pulp & Rock Pulp & Rock Pulp & Rock Pulp & Rock Pulp & Rock Pulp & Rock Pulp & Rock Pulp \\
\hline Microfacies & MF-1 & MF-1 & MF-1 & MF-1 & MF-1 & MF-2 & MF-2 & MF-2 & MF-2 & MF-2 & MF-3 & MF-3 & MF-3 & MF-3 & MF-3 \\
\hline $\mathrm{CaCO}_{3}$ & 99.20 & 99.22 & 99.24 & 99.22 & 99.14 & 99.18 & 99.16 & 99.34 & 99.33 & 99.18 & 99.03 & 98.35 & 99.20 & 99.26 & 99.29 \\
\hline $\mathrm{MgCO}_{3}$ & 0.80 & 0.78 & 0.7 & 0.78 & 0.86 & 0.82 & 0.84 & 0.66 & 0.67 & 0.82 & 0.97 & 1.65 & 0.80 & 0.74 & 0.71 \\
\hline $\mathrm{SiO}_{2}$ & 0.67 & 12.22 & 0.75 & 0.57 & 3.51 & 3.79 & 7.99 & 3.42 & 1.78 & 3.88 & 4.12 & 21.90 & 4.86 & 2.84 & 1.96 \\
\hline $\mathrm{Al}_{2} \mathrm{O}_{3}$ & 0.24 & 0.76 & 0.19 & 0.14 & 1.10 & 0.72 & 2.48 & 0.88 & 0.27 & 0.82 & 0.44 & 3.57 & 0.20 & 0.34 & 0.35 \\
\hline $\mathrm{Fe}_{2} \mathrm{O}_{3}$ & 0.11 & 0.27 & 0.09 & 0.08 & 0.18 & 0.27 & 0.19 & 0.20 & 0.20 & 0.21 & 0.25 & 0.46 & 0.12 & 0.13 & 0.15 \\
\hline $\mathrm{Na}_{2} \mathrm{O}$ & $<0.01$ & 0.01 & $<0.01$ & $<0.01$ & $<0.01$ & $<0.01$ & 0.02 & $<0.01$ & $<0.01$ & $<0.01$ & $<0.01$ & 0.03 & $<0.01$ & 0.01 & $<0.01$ \\
\hline $\mathrm{K}_{2} \mathrm{O}$ & 0.07 & 0.22 & 0.06 & 0.04 & 0.57 & 0.23 & 1.79 & 0.62 & 0.09 & 0.38 & 0.14 & 0.90 & 0.06 & 0.11 & 0.11 \\
\hline $\mathrm{TiO}_{2}$ & $<0.01$ & 0.03 & $<0.01$ & $<0.01$ & 0.02 & 0.02 & 0.03 & 0.02 & $<0.01$ & 0.02 & 0.01 & 0.08 & $<0.01$ & 0.01 & 0.01 \\
\hline $\mathrm{P}_{2} \mathrm{O}_{5}$ & 0.02 & 0.13 & 0.07 & 0.02 & 0.02 & 0.04 & 0.04 & 0.02 & 0.03 & 0.03 & 0.02 & 0.09 & 0.03 & 0.35 & 0.32 \\
\hline $\mathrm{MnO}$ & $<0.01$ & 0.01 & 0.01 & $<0.01$ & $<0.01$ & 0.01 & $<0.01$ & $<0.01$ & 0.01 & $<0.01$ & 0.02 & 0.01 & $<0.01$ & 0.01 & 0.01 \\
\hline $\mathrm{Cr}_{2} \mathrm{O}_{3}$ & $<0.002$ & $<0.002$ & $<0.002$ & $<0.002$ & $<0.002$ & $<0.002$ & 0.002 & $<0.002$ & $<0.002$ & $<0.002$ & $<0.002$ & 0.003 & $<0.002$ & $<0.002$ & $<0.002$ \\
\hline $\mathrm{Ba}$ & 3 & 3 & 7 & 4 & 7 & 5 & 27 & 9 & 2 & 6 & 3 & 21 & 4 & 3 & 3 \\
\hline $\mathrm{Ni}$ & $<20$ & $<20$ & $<20$ & $<20$ & $<20$ & $<20$ & $<20$ & $<20$ & $<20$ & $<20$ & $<20$ & $<20$ & $<20$ & $<20$ & $<20$ \\
\hline $\mathrm{Sc}$ & $<1$ & $<1$ & $<1$ & $<1$ & $<1$ & $<1$ & $<1$ & $<1$ & $<1$ & $<1$ & $<1$ & 2 & $<1$ & $<1$ & $<1$ \\
\hline LOI & 43.6 & 38.2 & 43.5 & 43.7 & 41.6 & 41.9 & 38.8 & 41.9 & 43.1 & 41.6 & 41.8 & 32.6 & 41.7 & 42.3 & 42.6 \\
\hline $\mathrm{Hf}$ & $<0.1$ & 0.1 & $<0.1$ & $<0.1$ & 0.1 & 0.1 & 0.2 & 0.2 & $<0.1$ & 0.2 & $<0.1$ & 0.5 & $<0.1$ & $<0.1$ & 0.1 \\
\hline Th & $<0.2$ & 0.4 & $<0.2$ & $<0.2$ & 0.2 & 0.3 & 0.3 & $<0.2$ & $<0.2$ & $<0.2$ & $<0.2$ & 0.9 & $<0.2$ & $<0.2$ & $<0.2$ \\
\hline $\mathrm{Zr}$ & 2.2 & 5.9 & 2.4 & 2.1 & 4.9 & 4.9 & 10.5 & 5.5 & 1.9 & 6.1 & 3.2 & 20.4 & 2.7 & 2.9 & 3.5 \\
\hline $\mathrm{Y}$ & 1.4 & 5.3 & 1.1 & 0.7 & 2.2 & 5.0 & 3.2 & 2.7 & 4.0 & 2.7 & 3.6 & 8.8 & 2.9 & 4.8 & 4.0 \\
\hline $\mathrm{La}$ & 1.2 & 4.4 & 0.7 & 0.6 & 2.5 & 3.8 & 3.5 & 2.7 & 2.7 & 2.6 & 2.9 & 10.8 & 2.1 & 3.0 & 2.9 \\
\hline $\mathrm{Ce}$ & 0.9 & 4.2 & 0.8 & 0.7 & 3.4 & 3.0 & 3.8 & 3.1 & 2.2 & 3.0 & 2.4 & 10.8 & 2.0 & 2.5 & 2.5 \\
\hline $\operatorname{Pr}$ & 0.17 & 0.79 & 0.33 & 0.09 & 0.40 & 0.56 & 0.53 & 0.47 & 0.42 & 0.41 & 0.42 & 2.06 & 0.31 & 0.42 & 0.44 \\
\hline $\mathrm{Nd}$ & 0.7 & 3.1 & 0.4 & 0.3 & 1.5 & 2.5 & 2.0 & 1.7 & 1.7 & 1.6 & 1.7 & 8.5 & 1.3 & 1.9 & 1.8 \\
\hline Sm & 0.11 & 0.59 & 0.11 & 0.05 & 0.25 & 0.50 & 0.31 & 0.31 & 0.38 & 0.27 & 0.31 & 1.67 & 0.25 & 0.29 & 0.43 \\
\hline $\mathrm{Eu}$ & 0.02 & 0.16 & $<0.02$ & $<0.02$ & 0.09 & 0.13 & 0.12 & 0.08 & 0.09 & 0.09 & 0.09 & 0.45 & 0.05 & 0.09 & 0.10 \\
\hline $\mathrm{Gd}$ & 0.10 & 0.79 & 0.06 & 0.07 & 0.33 & 0.54 & 0.45 & 0.39 & 0.39 & 0.38 & 0.42 & 1.68 & 0.27 & 0.47 & 0.50 \\
\hline $\mathrm{Tb}$ & 0.02 & 0.11 & 0.02 & $<0.01$ & 0.05 & 0.09 & 0.05 & 0.06 & 0.07 & 0.05 & 0.06 & 0.25 & 0.04 & 0.08 & 0.07 \\
\hline Dy & 0.08 & 0.73 & 0.10 & 0.05 & 0.32 & 0.50 & 0.38 & 0.32 & 0.43 & 0.30 & 0.38 & 1.33 & 0.35 & 0.39 & 0.48 \\
\hline Ho & 0.02 & 0.15 & 0.02 & $<0.02$ & 0.06 & 0.11 & 0.06 & 0.07 & 0.08 & 0.07 & 0.08 & 0.30 & 0.05 & 0.10 & 0.09 \\
\hline $\mathrm{Er}$ & 0.09 & 0.43 & 0.08 & 0.04 & 0.18 & 0.36 & 0.25 & 0.20 & 0.27 & 0.17 & 0.29 & 0.78 & 0.24 & 0.30 & 0.28 \\
\hline $\mathrm{Tm}$ & 0.01 & 0.06 & 0.01 & $<0.01$ & 0.02 & 0.05 & 0.04 & 0.03 & 0.04 & 0.03 & 0.04 & 0.11 & 0.02 & 0.05 & 0.04 \\
\hline $\mathrm{Yb}$ & 0.06 & 0.37 & 0.07 & $<0.05$ & 0.15 & 0.30 & 0.24 & 0.16 & 0.25 & 0.20 & 0.19 & 0.61 & 0.18 & 0.23 & 0.21 \\
\hline $\mathrm{Lu}$ & 0.01 & 0.06 & $<0.01$ & $<0.01$ & 0.02 & 0.04 & 0.03 & 0.02 & 0.03 & 0.03 & 0.04 & 0.09 & 0.03 & 0.04 & 0.04 \\
\hline ¿REEs & 4.89 & 21.24 & 3.80 & 2.60 & 11.47 & 17.48 & 14.96 & 12.31 & 13.05 & 11.90 & 12.92 & 48.23 & 10.09 & 14.66 & 13.88 \\
\hline $\mathrm{Y} / \mathrm{Ho}$ & 70.00 & 35.33 & 55.00 & n.c. & 36.67 & 45.45 & 53.33 & 38.57 & 50.00 & 38.57 & 45.00 & 29.33 & 58.00 & 48.00 & 44.44 \\
\hline $\mathrm{Eu} / \mathrm{Eu}^{*}$ & 1.01 & 1.22 & n.c. & n.c. & 1.63 & 1.32 & 1.65 & 1.20 & 1.24 & 1.45 & 1.29 & 1.42 & 1.02 & 1.24 & 1.13 \\
\hline $\mathrm{Ce} / \mathrm{Ce}^{*}$ & 0.47 & 0.54 & 0.38 & 0.71 & 0.81 & 0.48 & 0.66 & 0.66 & 0.49 & 0.69 & 0.51 & 0.55 & 0.58 & 0.52 & 0.52 \\
\hline $\mathrm{Pr} / \mathrm{Pr}^{*}$ & 1.16 & 1.19 & 3.29 & 1.11 & 1.00 & 1.09 & 1.08 & 1.15 & 1.17 & 1.05 & 1.14 & 1.16 & 1.06 & 1.04 & 1.13 \\
\hline $\mathrm{La} / \mathrm{La}^{*}$ & 2.11 & 1.47 & 0.21 & 1.28 & 1.48 & 2.70 & 1.59 & 1.27 & 1.83 & 1.65 & $\begin{array}{l}1.14 \\
1.97\end{array}$ & 1.58 & 2.15 & $\begin{array}{l}1.04 \\
3.02\end{array}$ & 1.94 \\
\hline
\end{tabular}




\section{Results}

\subsection{Petrography}

The petrographical analyses of the Lower Cretaceous carbonate succession, corroborated by previously published sedimentological and paleontological data [31,38], allows us to determine microfacies characteristics (Figure 2 and Figure 10) for the studied stratigraphic section in the Mescitli area. Three microfacies were identified by petrographic analysis based on their depositional textures and fauna. These are 1) Benthic foraminiferal packstone microfacies (MF-1), (2) Reworked skeletal grainstone/packstone microfacies (MF-2) and (3) Sponge spicule wackestone/mudstone microfacies (MF-3). Based on the benthic foraminiferal assemblages (Figure 2), the studied limestone succession was deposited during the Hauterivian-Albian interval (Figure 2 and Figure 10).

Benthic foraminiferal packstone microfacies (MF-1) is dominated by shallow water benthic foraminiferal packstone with rare wackestone layers (Figure 4a). It has a mud-supported texture (micritic matrix) (10-60\%), with frequent occurrence of small benthic foraminifera (30-50\%) such as miliolidae (Figure $4 a, b$ ) that are strongly micritized (Figure $4 b$ ). Rare thin-shelled ostracods are observed along with peloids (15-25\%) and fine-grain micritic intraclasts (5-10\%). The fine-grain intraclasts are commonly carbonate mud (30-40\%). In some parts of the thin section, sparite and micrite coexist. Besides, MF-1 show low biotic diversity and deep water bioclasts such as calcisphere and planktonic foraminifera are not observed. At the transition zone between MF-1 and MF-2 locally rare sand to silt-sized- plagioclase grains and basaltic extraclasts occur, that slightly decrease toward the top of the facies (Figure 4c).

Reworked skeletal grainstone/packstone microfacies (MF-2) comprise a high abundance skeletal component (30-50\%), peloids (5-10\%) and intraclasts (5-10\%) (Figure $4 \mathrm{~d}-\mathrm{f})$. The bioclastic components are represented by upward decreasing allochthonous skeletal fragments including, echinoids, molluscs, very rare small benthic foraminifera and undifferentiated shell fragments. The most frequent and common bioclasts through the MF-2 are echinoderms and bivalves. Other bioclasts, in order of abundance, are thin-shelled ostracods, sponge and sponge-spicules (Figure 4d-f). Most of the biotic components vary in size from 200 to $600 \mu \mathrm{m}$ long and are broken and reworked, except for small benthic foraminifera. Benthic foraminiferas are rare and infrequent. Relatively high biotic diversity of bioclasts is observed compared to the MF-1 (Figure 4-f). Sponge spicule wackestone/mudstone microfacies (MF-3) is differentiated from MF-2 mainly by its mud-dominated texture, the predominance of the sponge spicules and lower abundance of reworked bioclasts (Figure 4g-i). MF-3 mostly consists of wackestone to mudstone beds, as well as sponge spicules, rare reworked skeletal components, pseudo-peloids, and rare intraclasts occur. The intraclasts are composed of rounded micritic grains. Reworked skeletal components become thinner and sparser towards the top of MF-3 (Figure 4g), and the most upper part of the microfacies consists of rare reworked skeletal components (Figure $4 \mathrm{~h}$ ), but with a high abundance of planktonic forams, including Calcisphaerulidae (Figure 4i). MF-3 also contains locally common authigenic components (glauconitic grains). Deep-water bioclasts such as calcispheres and sponge spicule are observed at the top of MF-3.

\subsection{Major and Trace Elements}

The chemical analyses of the micritic limestone samples are represented in Table 1. Studied limestone samples exhibit low Mg-calcite characteristics with the main chemical formula of $\mathrm{Ca}_{98.35-99.34} \mathrm{Mg}_{0.66-1.65}\left(\mathrm{CO}_{3}\right)$. Major element contents in limestone (Mescitli Section) exhibit high $\mathrm{CaCO}_{3}$ varying from 98.35 to 99.35 (mole \%) and low $\mathrm{MgCO}_{3}$ ranging between 0.66 and 1.65 (mole $\%$ ). They have $\mathrm{SiO}_{2}$ contents ranging from 0.57 to $21.90 \mathrm{wt} \%$ (average: $4.95 \mathrm{wt} \%$ ), $\mathrm{Al}_{2} \mathrm{O}_{3}$ contents ranging from 0.14 to $3.57 \mathrm{wt} \%$ (average: $0.83 \mathrm{wt} \%$ ), $\mathrm{Fe}_{2} \mathrm{O}_{3}$ contents ranging from 0.08 to $0.46 \mathrm{wt} \%$ (average: $0.19 \mathrm{wt} \%$ ), $\mathrm{K}_{2} \mathrm{O}$ contents varying 0.04 to $1.79 \mathrm{wt} \%$ (average: $0.36 \mathrm{wt} \%$ ) and $\mathrm{P}_{2} \mathrm{O}_{5}$ varying from 0.02 to $0.35 \mathrm{wt} \%$ (average: $0.08 \mathrm{wt} \%$ ). $\mathrm{Na}_{2} \mathrm{O}$ (below detection limit (bdl), $<0,01$ to $0.03 \mathrm{wt} \%$ ), $\mathrm{MnO}(<0.01$ to $0.02 \mathrm{wt} \%), \mathrm{TiO}_{2}(<0.01$ to $0.08 \mathrm{wt} \%$; average: $0.03 \mathrm{wt} \%)$ and $\mathrm{Cr}_{2} \mathrm{O}_{3}(<0.002$ to $0.003 \mathrm{wt}$ 
$\%$ ) contents are all low (Table 1). The analytical results also show low contents of $\operatorname{Hf}(<0.1$ to $0.50 \mu \mathrm{g} / \mathrm{g}$ ), Sc $(<1$ to $2.0 \mu \mathrm{g} / \mathrm{g})$, Th $(<0.2-0.9 \mu \mathrm{g} / \mathrm{g}), \mathrm{Zr}(1.9-20.4 \mu \mathrm{g} / \mathrm{g})$ elements.

The studied limestones have variable $\Sigma$ REEs $(1.90-39.43 \mu \mathrm{g} / \mathrm{g}$ and ave. $10.74 \mu \mathrm{g} / \mathrm{g}), \mathrm{Y}(0.70-8.80 \mu \mathrm{g} / \mathrm{g}$; ave. $3.49 \mu \mathrm{g} / \mathrm{g})$ and Ho $(<0.02$ to 0.30 ; ave. $0.09 \mu \mathrm{g} / \mathrm{g})$ contents. Their Y/Ho (29.33-70.00; ave. 46.26) and $\mathrm{Eu} / \mathrm{Sm}(0.18-0.39$; ave. 0.28$)$ ratios are mostly similar to those of seawater while their $\mathrm{Sm} / \mathrm{Yb}$ (1.26-2.74; ave. 1.68) ratios are slightly higher than those of modern seawater [59] (Table 1). Following normalization of REEs to post-Archean Australian Shale (PAAS; [68]) the limestone samples exhibit (i) depleted LREE relative to HREE $(\mathrm{Nd} / \mathrm{Yb})_{\mathrm{N}}(0.46-1.12$; average 0.72$)$ and $(\operatorname{Pr} / \mathrm{Yb})_{\mathrm{N}}(0.50-1.40 ; 0.73)$ (ii) negative $\mathrm{Ce} / \mathrm{Ce}^{*}(0.38-0.81$; ave. 0.57$)$ (iii) slight positive $\mathrm{Eu} / \mathrm{Eu}^{*}(1.01-1.65$; ave. 1.29$)$, (iv) slightly flat $\mathrm{Pr} / \mathrm{Pr} *$ (1.00-3.29; ave. 1.26) anomalies and (v) positive La/La* anomaly (0.21-3.02; ave. 1.75). The samples mostly plot in area IIIb of the $\mathrm{Pr} / \mathrm{Pr}^{*}$ vs. Ce/Ce* ratios [68], which confirm that the Ce anomalies are not an artefact of $\mathrm{La}-$ interference (Figure $5 \mathrm{a}$ ). Eu/Eu* ratios exhibit no correlation with $\mathrm{Ba} / \mathrm{Sm}$ (Figure $5 \mathrm{~b}$ ). Ce/Ce* ratios show fluctuation (Table 1) with a steady increase throughout the MF-1 part of the studied section. The uppermost part of MF-1 exhibits slightly lower $\mathrm{Ce} / \mathrm{Ce}$ anomalies and is followed by a sharp decrease in the $\mathrm{Ce} / \mathrm{Ce}^{*}$ anomalies at the base of MF-2. MF-2 and MF-3 are represented by relatively low $\mathrm{Ce} / \mathrm{Ce}^{*}$ anomalies. There is no significant difference in $\mathrm{Ce}$ anomaly between MF-2 and MF3.
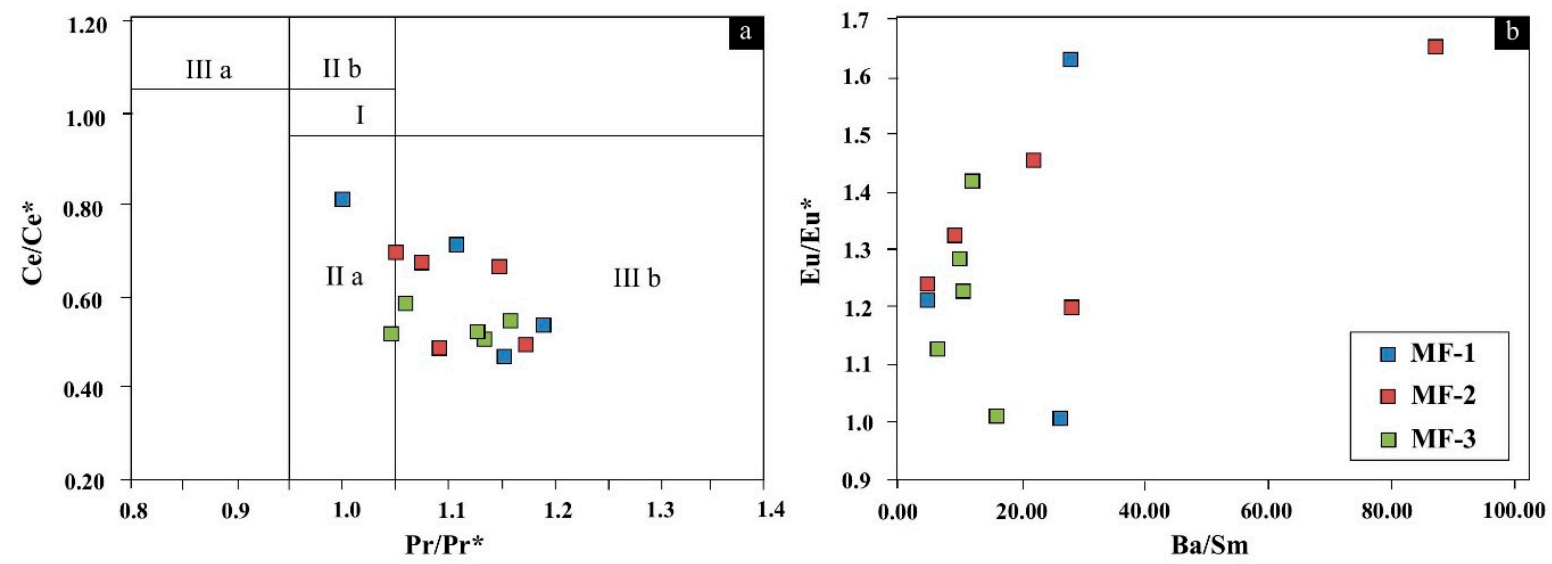

Figure 5. Plots of the $\mathrm{Pr} / \mathrm{Pr}^{*}$ vs. Ce/Ce* ratios diagram [69] (a), and $\mathrm{Ba} / \mathrm{Sm}$ vs. $\mathrm{Eu} / \mathrm{Eu} u^{*}$ ratios (b) of studied limestones. See the text for further details.

\section{Discussion}

\subsection{Siliciclastic Impurities}

To reveal the possible potential influence of terrigenous input on paleoredox indicators within the studied limestone, it is necessary to identify possible contamination by siliciclastics. This is important because contamination by terrestrial clays can control the primary REEs $+Y$ contents of ancient marine carbonates $[4,6,71,72]$. A small quantity of terrestrial particulate matter (i.e., shale), which has high REE contents with distinctly non-seawater-like patterns [73], may dramatically modify original REE patterns and cause a decrease in both the extent of LREE depletion and Y/Ho ratios [3,4,74]. Several lines of evidence suggest that the studied limestone displays a diagnostic seawater signature: (1) negative Ce anomalies (0.38-0.81; average 0.57), (2) depleted LREE and (3) superchondritic Y/Ho (average 46.26) (Figure 6a) (e.g., [4]). Although the limestone exhibits a slight enrichment of LREE compared to modern seawater of South Pacific deep water [11] their PAAS normalized patterns exhibit a seawater-like signature compared to the North American Shale Composite (Figure 6a,b) [75]. Furthermore, their general PAAS normalized patterns (i.e., $\mathrm{Ce}^{*}$ with an average of $0.57 ; \mathrm{Nd} / \mathrm{Yb}_{\mathrm{N}}$ with an average of $0.72 ; \mathrm{Pr} / \mathrm{Yb}_{\mathrm{N}}$ with an average of 0.73 values) are compatible with well-preserved brachiopods $[8,75]$ (Figure 6b,c). 

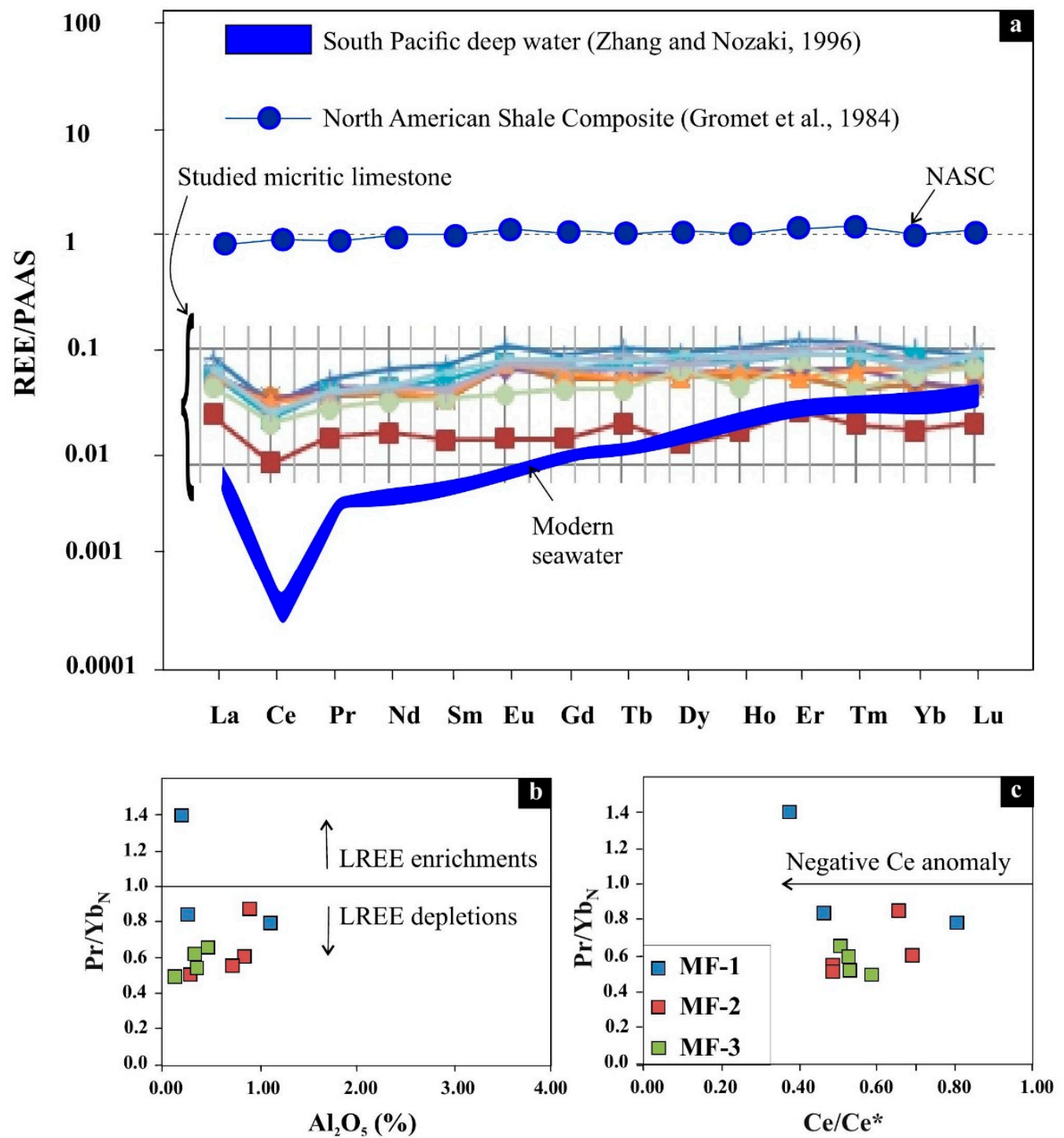

Figure 6. PAAS-normalized REE patterns of the studied limestone succession (a). Plot of the $\operatorname{Pr} / \mathrm{Yb}_{\mathrm{N}}$ values vs $\mathrm{Al}_{2} \mathrm{O}_{3}$ (wt \%) contents $(\mathbf{b})$ and $\mathrm{Pr} / \mathrm{Yb}_{\mathrm{N}}$ value vs. $\mathrm{Ce} / \mathrm{Ce}$ ratios (c). Modern seawater data from South Pacific deep water [11] and North American Shale Composite from [76].

The $\mathrm{Y} / \mathrm{Ho}$ ratios can be used as a tracer to assess whether carbonate samples reflect primary marine signature or siliciclastic components [2,4,77-79]. $\mathrm{Y}$ and Ho are isovalent trace elements which have a similar charge and radius, and they are considered to display extremely coherent behaviour as twin pairs in a geochemical system characterized by charge-and-radius-controlled (CHARAC) [10]. According to the previous work $[77,78,80]$, an aqueous marine system is characterised by non-CHARAC trace element behaviour, and electron structure must be considered as an important additional parameter which may cause trace element fractionation processes such as chemical complexation. The complexation behaviour of a trace element is additionally influenced by its electron configuration and by the character of chemical bonding between a central ion and a ligand $[79,80]$. For this reason, Ho is scavenged more readily from seawater than $Y$ due to differences in geochemical behaviour in surface complexation [79-84]. According to the literature, high $\mathrm{Y} / \mathrm{Ho}$ ratios (average of $61 \pm 12$ ) occur in the upper $200 \mathrm{~m}$ of seawater [7,11,12,64,85-91]. However, other studies have proposed that typical Y/Ho ratios in marine carbonates that are free of contamination from terrigenous material show a wider range of values (44-74) or a chondritic value of 28 [78,80]. The studied limestones display high $\mathrm{Y} / \mathrm{Ho}$ ratios with an average of $46.26(29.33-70.00)$, which is consistent with detritus-free marine sediments 
(average 45.50) [69]. Further, the lack of correlation between $\mathrm{Y} / \mathrm{Ho}$ ratios, $\mathrm{Ce} / \mathrm{Ce}^{*}$, and $\mathrm{Al}$ and $\mathrm{Zr}$ contents in the studied limestone implies little or negligible terrestrial contamination [74].

Finally, several trace elements including $\mathrm{Hf}, \mathrm{Sc}, \mathrm{Th}, \mathrm{Zr}$ and $\mathrm{Al}_{2} \mathrm{O}_{3}$ are considered to be particularly sensitive to shale contamination, as they occur in detrital alumosilicate minerals in much greater volume in average shale than in marine carbonates $[4-6,17-19,64,71,85,92,93]$. The studied micritic limestones predominantly exhibit low Hf ( $<0.02$ to $0.5 \mu \mathrm{g} / \mathrm{g})$, Sc $(<1$ to $2 \mu \mathrm{g} / \mathrm{g}) \mathrm{Th}(<0.2$ to $0.9 \mu \mathrm{g} / \mathrm{g})$ contents, which supports the observation that contamination by detrital minerals is minor to negligible (Table 1). Relatively low $\mathrm{Zr}(1.90-20.40 \mu \mathrm{g} / \mathrm{g}$, an average of $5.27 \mu \mathrm{g} / \mathrm{g})$ and $\mathrm{Al}_{2} \mathrm{O}_{3}(0.14-3.57 \mathrm{wt} \%$, an average of $0.83 \mathrm{wt} \%$ ), with a good correlation between $\mathrm{Zr}$ and $\mathrm{Al}_{2} \mathrm{O}_{3}$, suggest a minor amount of shale contamination (Figure 7a). However, total REE concentration is poorly correlated with $\mathrm{Zr}$ and $\mathrm{Al}_{2} \mathrm{O}_{3}$, implying that this small volume does not dramatically contaminate the REE concentration in these samples [2] (Figure $7 \mathrm{~b}, \mathrm{c}$ ). Plotting $\mathrm{Y} / \mathrm{Ho}, \mathrm{Eu} / \mathrm{Eu}^{*}$ and $\mathrm{Ce} / \mathrm{Ce}^{*}$ versus and $\mathrm{Zr}$ contents in Figure $7 \mathrm{~d}-\mathrm{f}$ shows no positive correlation, as would be expected if there was low detrital contamination [3-5].
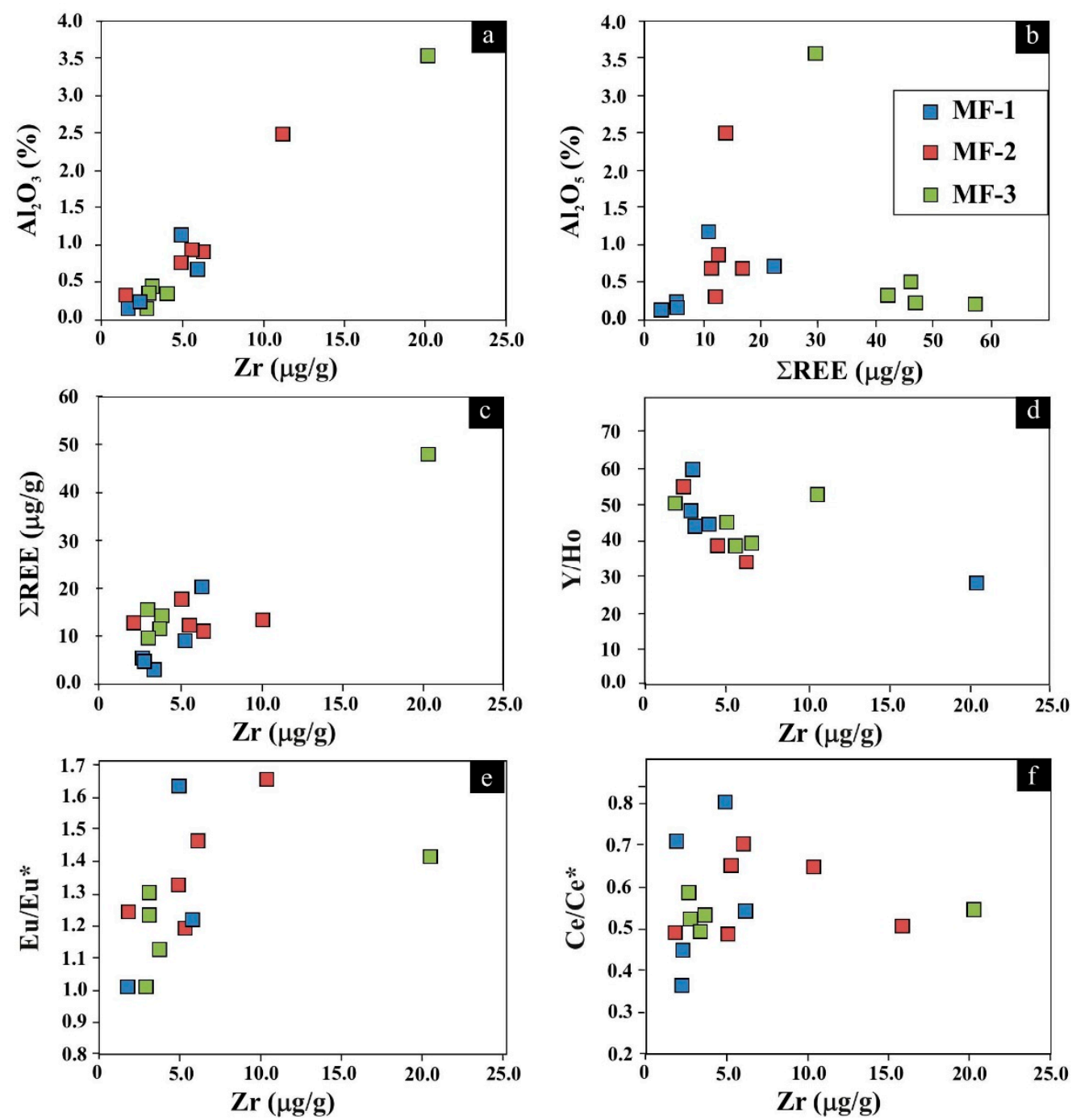

Figure 7. Plots of the $\mathrm{Zr}\left(\mu \mathrm{g} / \mathrm{g}\right.$ ) vs. $\mathrm{Al}_{2} \mathrm{O}_{3}$ (wt \%) contents (a); $\Sigma \mathrm{REE}\left(\mu \mathrm{g} / \mathrm{g}\right.$ ) vs. $\mathrm{Al}_{2} \mathrm{O}_{3}$ (wt \%) contents (b); $\mathrm{Zr}(\mu \mathrm{g} / \mathrm{g})$ vs. $\Sigma$ REE $(\mu \mathrm{g} / \mathrm{g})$ contents (c); Y/Ho ratios vs. $\mathrm{Zr}(\mu \mathrm{g} / \mathrm{g})$ contents (d); $\mathrm{Zr}(\mu \mathrm{g} / \mathrm{g})$ contents vs. $\mathrm{Eu} / \mathrm{Eu}^{*}$ ratios $(\mathbf{e}) ; \mathrm{Zr}(\mu \mathrm{g} / \mathrm{g})$ contents vs. Ce/Ce* ratios (f).

To sum up, the contamination of carbonate samples by terrestrial materials can be defined as minor or negligible based on these multiple and independent analyses including (1) their seawater 
signature; (2) similar $\mathrm{Y} / \mathrm{Ho}$ ratios to those of the marine carbonates free of contamination and (3) lower $\mathrm{Sc}$, Th, $\mathrm{Zr}$ and $\mathrm{Al}_{2} \mathrm{O}_{3}$ contents as discussed above.

\subsection{Diagenetic Influence}

REEs, in particular $\mathrm{Ce}$ and $\mathrm{Eu}$, are widely used to reconstruct the redox evolution of the carbonate system $[1,64,85,94]$. Carbonate minerals, especially calcite, can be considered long-term repositories of lanthanides [8,95]. Therefore, carbonate sedimentologists have focused on a wide range of marine carbonate components such as reefal microbialites (e.g., [6,17]), reefal carbonate (e.g., [4]), laminae of ooids (e.g., [85]), belemnites (e.g., [8]) and micritic limestones (e.g., [86]) for the reconstruction of ancient paleoenvironmental conditions. Their REE + Y patterns do not always exhibit a typical seawater signature, even though the REE signature is thought to be inherited from their parental seawater [1-4,18,82,87-90] because original REE patterns can be significantly altered during diagenesis under high water-rock ratios $[4,6,81,91]$. However, complete mineral dissolution is necessary to lead to an effective loss of trace elements, including REEs, from the mineral lattice (e.g., [95]).

Many studies have focused on using REEs to provide a better understanding of the influence of thermodynamic and kinetic parameters on the partitioning of individual REEs during calcite precipitation $[90,91,95,96]$. Mineral dissolution is considered unlikely to destroy the geological record encoded by the distribution pattern of REEs in calcites based on experimental studies, though some have questioned this interpretation because of differences between the experimental system and natural settings (e.g., REE concentration in solution) [96]. Further, a large amount of information on REEs in natural carbonates have been compiled [95,96], and several parameters have been investigated to assess the potential diagenetic influence on the REE signature of carbonates [1-4]. It has been shown that the progressive REE scavenging during post-depositional modification may produce a positive correlation between the Ce anomaly and REE [70,71,91]. However, our samples do not display a notable positive correlation between $\mathrm{Ce}$ and REE content (Figure 8a). Furthermore, the studied carbonates show a negative correlation between $\mathrm{Eu} / \mathrm{Eu}^{*}$ and $\mathrm{REE}$ concentration (Figure 8b), implying that such a diagenetic influence is absent [91]. Finally, a negative correlation between $\mathrm{Ce} / \mathrm{Ce}^{*}$ and $\mathrm{La} / \mathrm{Sm}_{\mathrm{N}}$ ratios have been used as evidence of diagenetic influence on Ce [97-99], and this correlation is not apparent in our carbonates (Figure 8c). Similarly, an absence of correlation between $\mathrm{Ce} / \mathrm{Ce}$ and $\mathrm{Eu} / \mathrm{Eu}^{*}$ implies a negligible or absence of influence of post-depositional alteration on the measured $\mathrm{Ce} / \mathrm{Ce}^{*}[3,7,74,84,87,100]$. Our samples display a weak correlation (Figure $8 \mathrm{~d}-\mathrm{f}$ ), which implies negligible or no diagenetic impact on Ce anomalies. This conclusion is also supported by petrographic observations of the micritic limestone, which do not show significant recrystallization.

Given these conditions, the relationship between $\mathrm{Ce} / \mathrm{Ce}^{*}$ and $\mathrm{Pr} / \mathrm{Pr}^{*}$ can be used to characterize redox conditions using shale-normalized REE contents [69]. In assessing whether an apparent Ce anomaly is true, and not a function of La-enrichment, the data was analysed using the Ce/Ce* versus $\operatorname{Pr} / \operatorname{Pr}^{*}$ analysis [69] (Figure 5a), whereby area (I) no Ce anomaly; (IIa) positive La anomaly causes apparent negative Ce anomaly; ( $\mathrm{Ilb})$ negative La anomaly causes apparent positive Ce anomaly; (IIIa) real positive Ce anomaly; (IIIb) real negative Ce anomaly; (IV) positive La anomaly disguises positive Ce anomaly $[69,99]$. The position of samples from this study in area IIIb indicates that they display real $\mathrm{Ce}$ anomalies (Figure $5 \mathrm{a}$ ). In addition, $\mathrm{Eu} / \mathrm{Eu}^{*}$ can be contaminated by interference with Ba during ICP-MS analysis [101], but Eu/Eu* ratios exhibit no correlation with $\mathrm{Ba} / \mathrm{Sm}$, implying that calculated anomalies are real positive Eu anomalies (Figure 5b). 

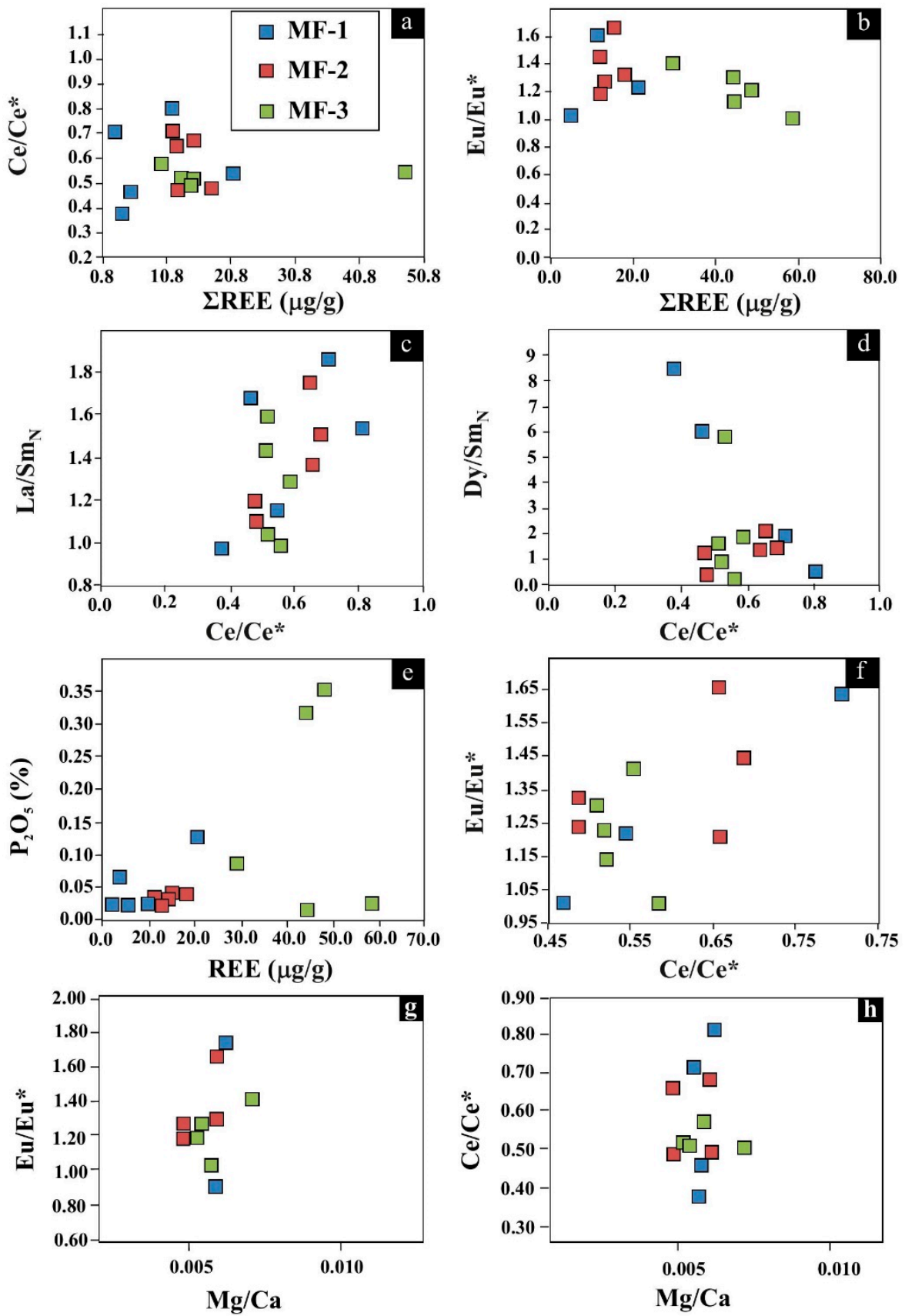

Figure 8. Plots of the $\Sigma$ REE ( $\mu \mathrm{g} / \mathrm{g})$ contents vs. Ce/Ce* ratios (a); $\Sigma \mathrm{REE}(\mu \mathrm{g} / \mathrm{g})$ contents vs. $\mathrm{Eu} / \mathrm{Eu}^{*}$ ratios (b); Ce/Ce* vs. La/Sm $/ \mathrm{N}$ ratios (c); Ce/Ce* vs. Dy/Sm $\mathrm{Sm}_{\mathrm{N}}$ ratios (d); $\Sigma \mathrm{REE}\left(\mu \mathrm{g} / \mathrm{g}\right.$ ) vs. $\mathrm{P}_{2} \mathrm{O}_{5}$ (wt \%) contents (e); $\mathrm{Eu} / \mathrm{Eu}^{*}$ vs. $\mathrm{Ce} / \mathrm{Ce}^{*}$ ratios (f); $\mathrm{Mg} / \mathrm{Ca}$ vs $\mathrm{Eu} / \mathrm{Eu}^{*}$ (g) and $\mathrm{Mg} / \mathrm{Ca}$ vs. $\mathrm{Ce} / \mathrm{Ce}$ ratios (h).

It has been shown that the micritic limestones mainly show a seawater signature, with LREE depletion, positive $\mathrm{La}$ anomaly $\left(\mathrm{La}^{*}\right)$ and a mostly negative $\mathrm{Ce}$ anomaly $\left(\mathrm{Ce} / \mathrm{Ce}{ }^{*}=0.38\right.$ to 0.81 , average 0.57). However, they also exhibit a wide-range of Eu anomalies $\left(\mathrm{Eu}^{*} / \mathrm{Eu}=1.01-1.65 ; 1.29\right)$. This pattern is missing in the general characteristics of normal marine carbonates [102] and is generally considered as an indicator of reducing, high-temperature fluids $[77,83,103,104]$. Similar patterns are recorded in many distinct marine systems affected by hydrothermal fluids associated with ferromagnesian rocks [71]. Such hydrothermal fluids are usually reported at mid-ocean ridges and back-arc spreading tectonic setting, where water-rock interactions with mafic rocks provide additional REE to ambient seawater $[69,77,80]$. Therefore, the $\mathrm{Eu} / \mathrm{Eu}^{*}$ ratios in this study may imply water-rock interaction with basalts. However, previous studies have shown that basaltic rocks are absent throughout the 
Lower Cretaceous, and there is no evidence of Early Cretaceous magma generation in the study area (Eastern Pontide, NE Turkey). Although it is widely accepted that the Early Cretaceous was a stable tectonic regime due to a lack of igneous activity [50,61]. The eastern Pontide experienced multistage basaltic magma generation during the Late Cretaceous [43,49] and early Cenozoic acidic magma generation is also recorded [44-46,63]. This Upper Cretaceous to Cenozoic magma generation has led to recrystallisation and geochemical modification of the underlying dolomites at a late-stage of their diagenetic history [32-34]. However, the studied Lower Cretaceous limestones do not show petrographical evidence of such recrystallisation (Figure $4 \mathrm{a}, \mathrm{b}$ ). Furthermore, the studied limestone samples exhibit low Mg-calcite chemistries (Ca98.81-99.52 $\mathrm{Mg}_{0.48-1.19}\left(\mathrm{CO}_{3}\right)$ ) [105], indicating that they are chemically stable [106-113]. Further, there is neither petrographical evidence for recrystallization which associated with Late Cretaceous to Cenozoic magma generation nor geochemical pieces of evidence, for example, the lack of apparent correlation between $\mathrm{Mg} / \mathrm{Ca}$ vs. $\mathrm{Ce} / \mathrm{Ce}^{*}$ and $\mathrm{Eu} / \mathrm{Eu}^{*}$ ratios which imply less influence of late diagenetic processes on their REE chemistry (Figure 8g,h). Therefore, Late Cretaceous to Cenozoic magma generation during this later diagenetic stage is probably not responsible for high the $\mathrm{Eu} / \mathrm{Eu}^{*}$ ratios of the studied limestone.

Nevertheless, Lower Cretaceous calc-alkaline lamprophyre and high- $\mathrm{Nb}$ alkaline basaltic dykes have been discovered in the Eastern Pontide [114], and this may have provided hydrothermal fluids to the depositional environment, which changed the temperature and/or redox conditions prior to diagenetic stabilization (e.g., [81]). To test this, Sm/Yb vs. Eu/Sm and La/Yb vs. La/Sm plots were constructed (Figure 9a,b). The data show an overlap with hydrogenetic-Fe-Mn crusts and relatively higher $\mathrm{La} / \mathrm{Yb}_{\mathrm{N}}$ values than seawater are observed, implying the presence of some early absorption processes [3,115] (Figure 9b). It has been proposed that hydrothermal fluid possess higher Sm/Yb and chondritic Y/Ho values ( 28) than modern seawater [71]. Plotting Y/Ho versus Sm/Yb (Figure 9c), studied samples overlap with the samples of Pongola Iron Fm. which were affected by hydrothermal fluid during their sedimentation processes [71]. They also plot on the line of hydrothermal fluid $(1-5 \%)$ suggesting a contribution of hydrothermal fluid Figure 9c. Although the studied samples have relatively lower Eu/Sm ratio compared to the high-T hydrothermal fluids. They possess similar Eu/Sm ratio to the hydrogenic Fe-Mn crusts (Figure 9d) and samples plot in an area between seawater and hydrogenetic- Fe-Mn crusts which may confirm the influence of the hydrothermal fluid. To sum up, even though the studied limestone formed in an open marine environment, (i) the positive Eu anomalies, (ii) high $\mathrm{Sm} / \mathrm{Yb}$ and $\mathrm{La} / \mathrm{Yb}_{\mathrm{N}}$ ratios and (iii) the $\mathrm{Y} / \mathrm{Ho}$ range between seawater and hydrogenetic Fe-Mn crusts suggest some modification by hydrothermal fluids which are most likely to be associated with Early Cretaceous magma generation (Hauterivian-Albian) [77,83,103,104,116,117]. 

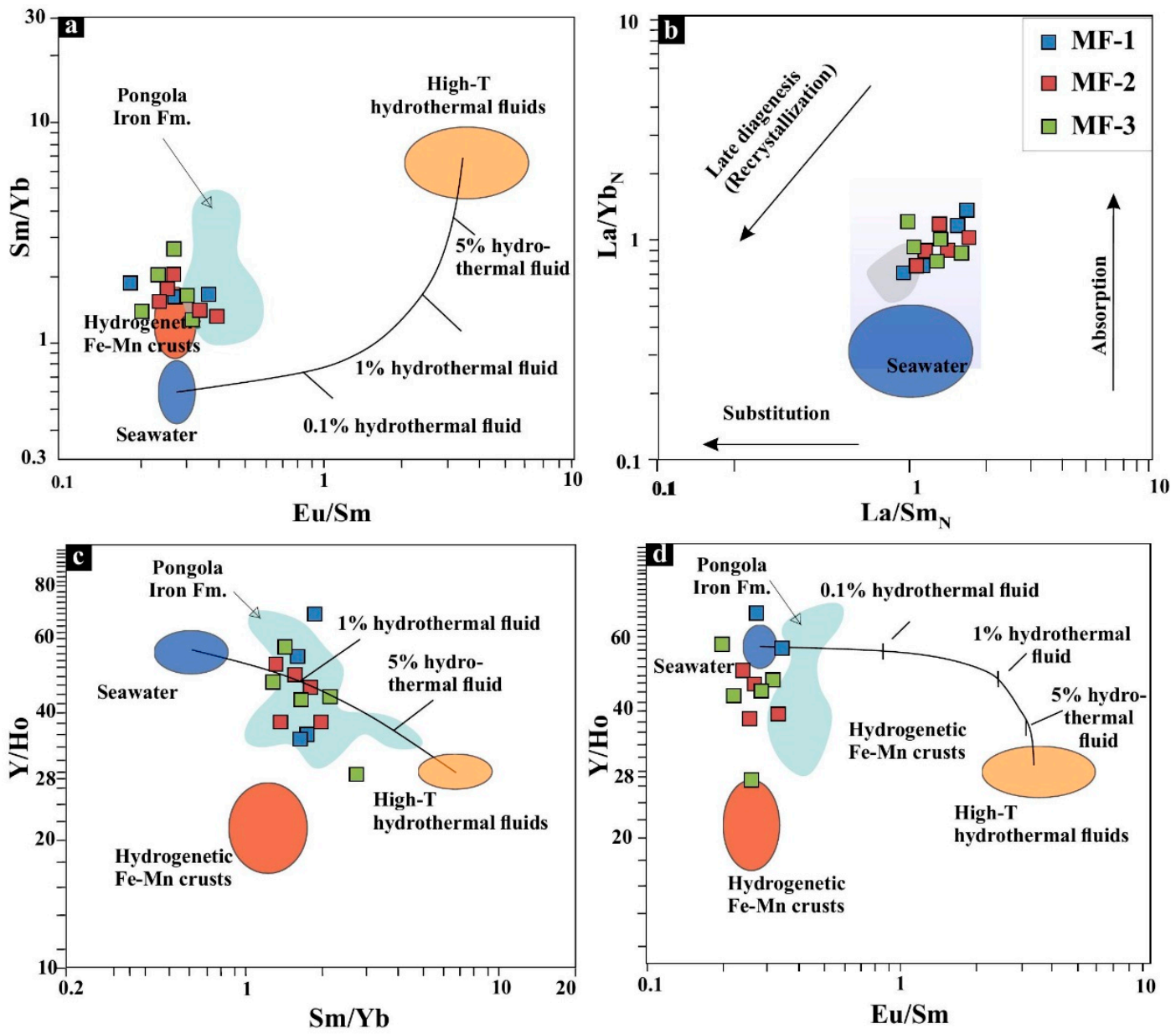

Figure 9. Plots of the $\mathrm{Eu} / \mathrm{Sm}$ vs. $\mathrm{Sm} / \mathrm{Yb}(\mathbf{a}) ;(\mathrm{La} / \mathrm{Sm}) \mathrm{N}$ vs. $(\mathrm{La} / \mathrm{Yb}) \mathrm{N}(\mathbf{b}) ; \mathrm{Sm} / \mathrm{Yb}$ vs. Y/Ho (c); and $\mathrm{Eu} / \mathrm{Sm}$ vs. Y/Ho (d) $[21,71,115]$.

\subsection{Early Cretaceous Paleoenvironmental Implications}

It has been shown that the studied limestones mostly display a seawater signature including (1) negative Ce anomalies, (2) superchondritic $\mathrm{Y} / \mathrm{Ho}(47 \pm 4)$, and depleted LREE relative to HREEs $\left((\mathrm{Nd} / \mathrm{Yb})_{\mathrm{N}}=0.46-1.12\right.$; ave. 0.72 and $\left.(\mathrm{Pr} / \mathrm{Yb})_{\mathrm{N}}=0.50-1.40 ; 0.73\right)$ (Figures $6 \mathrm{a}-\mathrm{c}$ and 10$)$. The $\mathrm{Ce}^{*}$ anomaly in carbonates is considered as a superior proxy for revealing the redox-state of the ancient seawater $[3,8,74]$. The studied samples exhibit negative $\mathrm{Ce}^{*}$ anomalies, typical of modern oxygenated seawater $[9,77,78,80,84,91,118]$. However, anoxic conditions may weaken the Ce depletion as a result of redox reactions leading $\mathrm{Ce}^{3+}$ oxidation to insoluble $\mathrm{Ce}^{4+}$ because dissolved $\mathrm{Ce}^{3+}$ which is partially scavenged from seawater in the anoxic marine system $[13,20,119,120]$. The lack of significant negative-Ce anomalies in many marine sediments has been considered as evidence of the anoxic seawater $[100,121]$. Besides, it has been suggested that a pronounced negative $\mathrm{Ce}^{*}$ anomaly can be divided into three: (a) smaller than $<0.5$; (b) $\sim 0.6-0.9$ and (c) $~ 0.9-1.0$ which represents oxic, suboxic and anoxic marine water, respectively [19].

The studied limestone is interpreted to have experienced progressive modification through interaction with reducing, high-temperature diagenetic fluids, and this caused the slight enrichment of $\mathrm{Eu}$. However, no notable positive correlation between Eu anomalies versus Ce are present, which may indicate that modification of Eu was not accompanied by the modification of their $\mathrm{Ce}^{*}$ values. Consequently, the wide range of negative Ce distributions may point to a change in paleoceanographic conditions from slightly suboxic to oxic paleo-redox state of ancient seawater but still remaining $<0.9$ [3]. MF-1 located in the lower part of the studied limestone succession is interpreted to have been deposited in an inner platform paleoenvironment during the Hauterivian-Aptian based on the 
microfacies characteristics and foraminifera assemblages (e.g., the high abundance of the benthic characteristics of foraminifera assemblages, lack of deep-water bioclasts and low biotic diversity) $[31,67]$ (Figure 1.) It exhibits a wide range of Ce anomalies (0.38-0.81), with a steadily increasing trend upward in the succession, coincident with interpreted increasing palaeo-water depth (Figure 10, Table 1). The uppermost part of MF-1 exhibits slightly weaker $\mathrm{Ce} / \mathrm{Ce}^{*}$ anomalies implying a relatively suboxic state of the ancient seawater. This is followed by a sharp decrease in the $\mathrm{Ce} / \mathrm{Ce}^{*}$ anomalies at the base of MF-2, suggesting a sudden change in the redox state of contemporaneous seawater. There is then a gradual transition to the overlying MF-3, indicating oxic seawater (Figure 10, Table 1) which remained relatively stable until the end of MF-3. This is despite the progressive deepening of the basin, which might have been caused a slight decrease in oxygenation as relative sea-level increased [15].
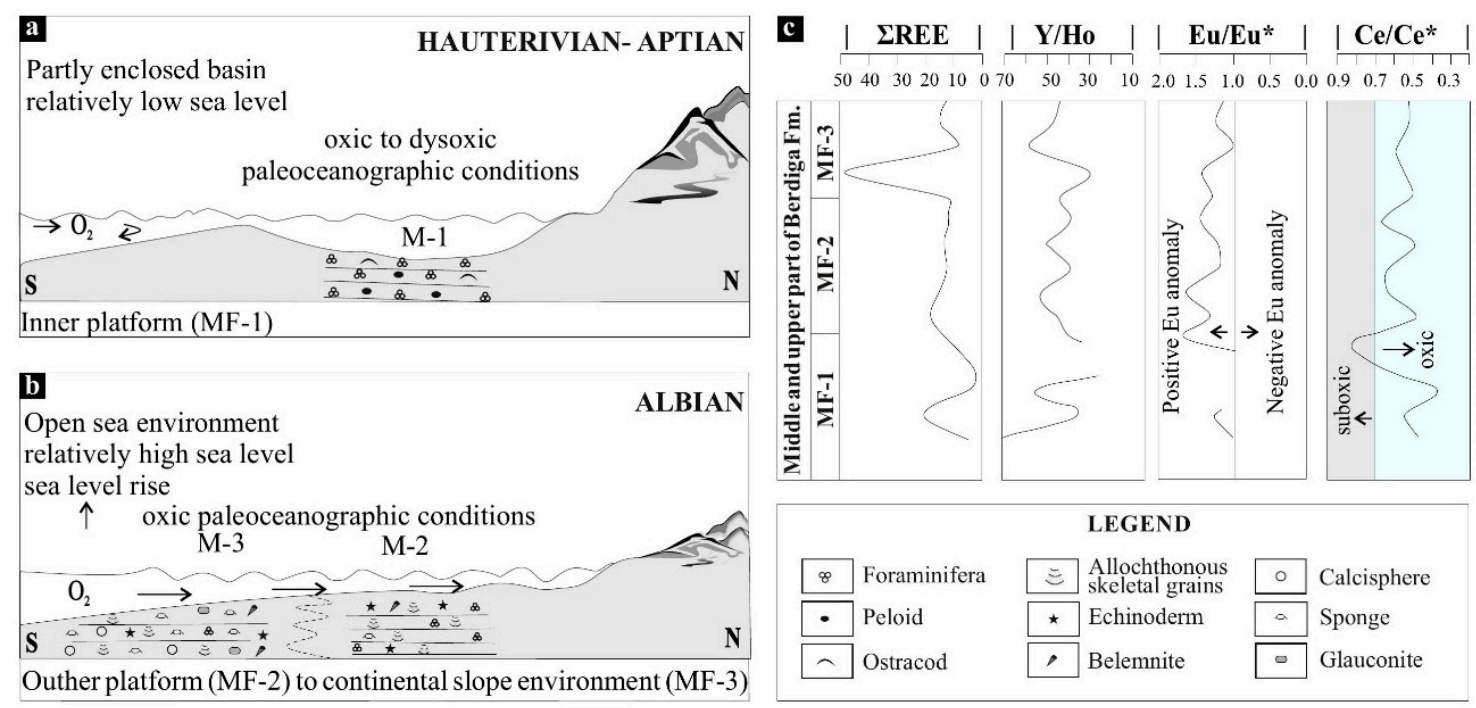

Figure 10. Diagrammatic sketch illustrating probable environment evolution of middle and upper part of the Berdiga Formation during the Hauterivian-Albian in Eastern Pontide. (a) During MF-1 deposition, the inner platform environment with relatively low sea level with oxic to dysoxic paleoceanographic conditions. (b) During MF-2 and MF-3 deposition, an outer platform to continental slope environment with relatively high relative sea level and a well-oxygenated open marine environment. (c) Inset showing the relative position of each phase with respect to $\Sigma \mathrm{REE}(\mu \mathrm{g} / \mathrm{g}) \mathrm{Y} / \mathrm{Ho}, \mathrm{Eu} / \mathrm{Eu}^{*}$ and Ce/Ce* variations. $\mathrm{Ce} / \mathrm{Ce}^{*}$ shows dyspoxic $\left(\mathrm{Ce}^{*}=0.71-0.81\right)$ conditions in most upper part of the MF-1. MF-1: benthic foraminiferal packstone microfacies corresponding to inner platform environment, MF-2: reworked skeletal grainstone/packstone microfacies corresponding to other platform, and MF-3: Sponge spicule wackestone-mudstone microfacies continental corresponding to slope environment.

The differences in microfacies characteristics and foraminifera assemblage between MF-1 and overlying MF-2 may also confirm a change in paleoceanographic conditions because MF- 2 is represented by the predominance of allochthonous bioclastic components which are broken and reworked, high biotic diversity and scarcity of small benthic foraminifera implying a deeper shelf environment relative to the MF-1. Furthermore, the presence of the rare plagioclase and basaltic extraclasts in the transition zone from MF-1 to MF-2 (Figure 4c) is likely associated with the basaltic magma generation, which has been recently reported [114]. This basaltic magma generation is probably caused by synsedimentary tectonic activity. The syn-sedimentary tectonic regime may also cause progressive deepening of the basin. Furthermore, the submarine basaltic magma generation may also influence on the sudden change in paleo-redox conditions of ancient depositional environment. This likely result in the oxygen-deficient conditions, which produce our relatively high $\mathrm{Ce} / \mathrm{Ce}^{*}$ data $(0.71$ to 0.81$)$ in the uppermost part of MF-1.

The $\mathrm{Ce} / \mathrm{Ce}^{*}$ anomaly at the MF1 / MF2 boundary is marked, and coincides with a change in facies from shallow water, benthic foraminiferal packstone to reworked skeletal packstone that is dominated by fragmented, allochthonous, largely heterotrophic fauna. This could reflect a facies transition from 
shallow water, platform top (MF1) to deeper water slope (MF2) setting, consistent with the overall deepening of the succession. However, the presence of fragmented organisms suggests depositional energy remained moderate, and water depths were not sufficiently deep for oxygenation to be reduced; the overlying MF3 sediments are more likely to be deeper water but remain oxic. The decrease in the $\mathrm{Ce} / \mathrm{Ce}^{*}$ anomaly coincides with a decrease in $\Sigma \mathrm{REE}, \mathrm{Y} / \mathrm{Ho}$ and Eu/Eu* anomaly (Figure 10). Dating of benthic foraminifera indicates that a timing that is broadly consistent with the onset of OAE1a [122], where global temperatures rose, and ocean acidification occurred as a result of rising $\mathrm{CO}_{2}$ concentrations during emplacement of Large Igneous Provinces. It is, therefore, possible that the MF1/MF2 boundary records this event, both in the increase in hydrothermal activity - which modified $\mathrm{Eu} / \mathrm{Eu}^{*}$ - and the decrease in seawater oxygenation that decreased $\mathrm{Ce} / \mathrm{Ce}^{*}$. In this sense, the change in facies from MF1 to MF2 might not simply reflect a rise in relative sea level, and it might also indicate decreasing carbonate productivity and preservation.

Paleo-redox evolution can be controlled by the function of temperature, fluid chemistry of paleo-oceanic system triggered by complex tectono-sedimentary evolution of the Eastern Pontide. It is therefore recommended that paleoceanographic studies demonstrate more conclusively the occurrence of oxygen-deficient conditions in the Tethys ocean, within the study area. Our results have the potential to contribute new information to this discussion because a paleoceanographic reconstruction of the studied section can be established based on the faunal content, microfacies characteristics, and REE data. MF-1 represents an inner platform setting with mostly oxic conditions during the Hauterivian-Aptian. However, a sudden change in redox-state of ancient seawater, corresponding dysoxic conditions, is recorded in the most upper part of the MF-1. This is followed by an abrupt deepening paleoenvironment with a relative increase in the oxic state of the seawater and the deposition of the deeper water microfacies (MF-2 and MF-3) above a sharp transition. This represents a relative sea-level rise triggered by the evolution of the Tethys in the Eastern Pontide resulting deepening of the basin and is also recorded in age-equivalent carbonates in NE Turkey [37]. Previous studies have indicated that the extensional tectonics and rifting in the Cretaceous in NE Turkey $[25,37,50,61]$ terminated in the middle Cretaceous, such that deeper paleoenvironmental conditions could be consistent with thermal subsidence, even though carbonate sedimentation continued until the end of Albian or Turonian $[25,37,123]$. Similarly, in this study, MF-1 represents an inner platform setting with mostly oxic conditions during the Hauterivian-Aptian. However, a sudden change in redox-state of ancient seawater, corresponding dysoxic conditions, is recorded in the most upper part of the MF-1 (Figure 10). This is followed by an abrupt deepening paleoenvironment with a relative increase in the oxic state of the seawater and the deposition of the deeper water microfacies (MF-2 and MF-3) above a sharp transition. Moreover, an abrupt paleoenvironmental change is represented by the presence of MF2 and MF3 which include dark grey limestones with chert nodules, mud-rich textures, allochthonous skeletal fragments and sponge spiculitics and presence of the planktonic organism, all consistent with deeper water sedimentation. These characteristics can be indicative of an increase in the water depth. The gradual transition to MF-3 with a predominance of mud-rich texture, a decrease in abundance of allochthonous skeletal fragments support the transgressively deepening of the paleoenvironment which continued up to late Albian. It has also been recorded the sponge spicule wackestone with Microhedbergella rischi within the most upper part of MF-3 [37,51]. Thus, the presence of the planktonic organism may characterise the deepest part of the paleoenvironment which corresponding to the slope [65]. Further, their REEs data confirm that their oxic conditions remained stable throughout the deeper facies (MF-2 and MF-3), even considering the distal microfacies. The current work, therefore, supports that the shallower part of the paleo-ocean remained relatively less oxic and became suboxic during the Late Aptian-Albian, while deeper facies, which display an overall transgressive motif, were developed in relatively more oxic paleo-oceanic conditions up to the end Albian (Figure 10). 


\section{Conclusions}

The study of the Lower Cretaceous limestone succession, corroborated by detailed microfacies analysis and REE geochemistry, allows us to present new data on ocean paleoredox conditions (Figure 10) and the extent of diagenetic alteration for the studied stratigraphical section in Mescitli area (Eastern Pontides, NE Turkey). Our primary results are as follows:

1. Analyzed micritic limestone samples mainly exhibit a seawater signature including (1) slight LREE depletion relative to the HREEs (ave. 0.72 of $\mathrm{Nd} / \mathrm{Yb}_{\mathrm{N}}$ and ave. 0.73 of $\mathrm{Pr} / \mathrm{Yb}_{\mathrm{N}}$ ), (2) negative Ce anomalies $\left(\mathrm{Ce}^{*} / \mathrm{Ce}=0.38-0.81\right.$; ave. 0.57$)$, (3) positive La anomaly ( $\mathrm{La}^{*} / \mathrm{La}=0.21-3.02$; ave. 1.75) and (4) superchondritic Y/Ho (ave. 46.26).

2. Micritic limestone also shows slight positive $\mathrm{Eu}^{*}$ anomalies $\left(\mathrm{Eu}^{*} / \mathrm{Eu}=1.01-1.65 ;\right.$ ave. 1.29$)$ and relatively higher $\mathrm{Sm} / \mathrm{Yb}\left(1.39-1.26\right.$; ave. 2.05) and $\mathrm{La} / \mathrm{Yb}_{\mathrm{N}}(0.68-1.35 ; 0.96)$ ratios compared to the modern seawater. This may imply the presence of water-rock interaction between parental seawater and basaltic rocks at elevated temperatures triggered by hydrothermal activity associated with Early Cretaceous basaltic magma generation.

3. The studied sections exhibit negative $\mathrm{Ce}^{*}$ anomalies, varying from 0.38 to 0.81 , which may confirm mostly oxic to dysoxic paleoceanographic conditions. Further, dyspoxic $\left(\mathrm{Ce}^{*}=0.71-0.81\right)$ conditions are also recorded in the most upper part of the MF-1 Microfacies during the late Aptian-early Albian.

4. The current work suggests that the shallower part of the paleo-ocean remained relatively less oxic and became suboxic during the Late Aptian-Albian, while deeper facies displaying overall transgressive trend were developed in relatively more oxic paleo-oceanic conditions up to end of Albian.

Author Contributions: Conceptualization, M.Ö.; writing-original draft preparation, M.Ö.; supervision, M.Z.K., I.A.-A., and C.H.; writing-review and editing, I.A-A. and C.H.; review and editing, C.H., R.K., and K.T. All authors have read and agreed to the published version of the manuscript.

Funding: Funding for this study partly originated from Scientific and Technological Research Council of Turkey (TUBITAK-ÇAYDAG, Project no: 115Y005) and Karadeniz Technical University, Turkey (KTU BAP, Project no: FBA-2015-5160; and 7341-FBA-2018-7341).

Acknowledgments: The corresponding author acknowledges the University of Manchester (UK) for facilitating her Post-Doc Research. ISA acknowledges the support from NSERC. Special thanks to Ali Keskin, Sefa İnan, Mert Oğuzhan Dinç, and Aslı Çağla for their help during the sampling period. The anonymous reviewers are also acknowledged for their improvements to the paper.

Conflicts of Interest: The authors declare no conflict of interest.

\section{References}

1. Franchi, F. Petrographic and geochemical characterization of the Lower Transvaal Supergroup stromatolitic dolostones (Kanye Basin, Botswana). Precambrian Res. 2018, 310, 93-113. [CrossRef]

2. Frimmel, H.E. Trace element distribution in Neoproterozoic carbonates as palaeoenvironmental indicator. Chem. Geol. 2009, 258, 338-353. [CrossRef]

3. Liu, X.M.; Hardisty, D.S.; Lyons, T.W.; Swart, P.K. Evaluating the fidelity of the cerium paleoredox tracer during variable carbonate diagenesis on the Great Bahamas Bank. Geochim. Et Cosmochim. Acta 2019, 248, 25-42. [CrossRef]

4. Nothdurft, L.D.; Webb, G.E.; Kamber, B.S. Rare earth element geochemistry of Late Devonian reefal carbonates, Canning Basin, Western Australia: Confirmation of a seawater REE proxy in ancient limestones. Geochim. Et Cosmochim. Acta 2004, 68, 263-283. [CrossRef]

5. Redivo, H.V.; Mizusaki, A.M.; Santana, A.V. REE patterns and trustworthiness of stable carbon isotopes of Salitre Formation, Irecê Basin (Neoproterozoic), São Francisco Craton. J. S. Am. Earth Sci. 2019, 90, 255-264. [CrossRef]

6. Webb, G.E.; Kamber, B.S. Rare earth elements in Holocene reefal microbialites: A new shallow seawater proxy. Geochim. Et Cosmochim. Acta 2000, 64, 1557-1565. [CrossRef] 
7. Alibo, D.S.; Nozaki, Y. Rare earth elements in seawater: Particle association, shale-normalization, and Ce oxidation. Geochim. Et Cosmochim. Acta 1999, 63, 363-372. [CrossRef]

8. Azmy, K.; Brand, U.; Sylvester, P.; Gleeson, S.A.; Logan, A.; Bitner, M.A. Biogenic and abiogenic low-Mg calcite (bLMC and aLMC): Evaluation of seawater-REE composition, water masses and carbonate diagenesis. Chem. Geol. 2011, 280, 180-190. [CrossRef]

9. Nozaki, Y. Rare earth elements and their isotopes. Encycl. Ocean Sci. 2001, 4, 2354-2366.

10. Piper, D.Z.; Bau, M. Normalized rare earth elements in water, sediments, and wine: Identifying sources and environmental redox conditions. Am. J. Anal. Chem. 2013, 4, 69-83. [CrossRef]

11. Zhang, J.; Nozaki, Y. Rare earth elements and yttrium in seawater: ICP-MS determinations in the East Caroline, Coral Sea, and South Fiji basins of the western South Pacific Ocean. Geochim. Et Cosmochim. Acta 1996, 60, 4631-4644. [CrossRef]

12. Zhang, J.; Nozaki, Y. Behavior of rare earth elements in seawater at the ocean margin: A study along the slopes of the Sagami and Nankai troughs near Japan. Geochim. Et Cosmochim. Acta 1998, 62, 1307-1317. [CrossRef]

13. Sholkovitz, E.R.; Landing, W.M.; Lewis, B.L. Ocean particle chemistry: The fractionation of rare earth elements between suspended particles and seawater. Geochim. Et Cosmochim. Acta 1994, 58, 1567-1579. [CrossRef]

14. Elderfield, H. The oceanic chemistry of the rare-earth elements. Philos. Trans. R. Soc. Lond. Ser. A Math. Phys. Sci. 1988, 325, 105-126.

15. Caetano-Filho, S.; Paula-Santos, G.M.; Dias-Brito, D. Carbonate REE + Y signatures from the restricted early marine phase of South Atlantic Ocean (late Aptian-Albian): The influence of early anoxic diagenesis on shale-normalized REE + Y patterns of ancient carbonate rocks. Palaeogeogr. Palaeoclimatol. Palaeoecol. 2018, 500,69-83. [CrossRef]

16. Kim, J.H.; Torres, M.E.; Haley, B.A.; Kastner, M.; Pohlman, J.W.; Riedel, M.; Lee, Y.J. The effect of diagenesis and fluid migration on rare earth element distribution in pore fluids of the northern Cascadia accretionary margin. Chem. Geol. 2012, 291, 152-165. [CrossRef]

17. Li, F.; Webb, G.E.; Algeo, T.J.; Kershaw, S.; Lu, C.; Oehlert, A.M.; Tan, X. Modern carbonate ooids preserve ambient aqueous REE signatures. Chem. Geol. 2019, 509, 163-177. [CrossRef]

18. Qing, H.; Mountjoy, E.W. Rare earth element geochemistry of dolomites in the Middle Devonian Presqu'ile barrier, Western Canada Sedimentary Basin: Implications for fluid-rock ratios during dolomitization. Sedimentology 1994, 41, 787-804. [CrossRef]

19. Chen, J.; Algeo, T.J.; Zhao, L.; Chen, Z.Q.; Cao, L.; Zhang, L.; Li, Y. Diagenetic uptake of rare earth elements by bioapatite, with an example from Lower Triassic conodonts of South China. Earth Sci. Rev. 2015, 149, 181-202. [CrossRef]

20. De Baar, H.J.; German, C.R.; Elderfield, H.; Van Gaans, P. Rare earth element distributions in anoxic waters of the Cariaco Trench. Geochim. Et Cosmochim. Acta 1988, 52, 1203-1219. [CrossRef]

21. Mongelli, G.; Sinisi, R.; Paternoster, M.; Perri, F. REEs and U distribution in P-rich nodules from Gelasian Apulian Tethyan carbonate: A genetic record. J. Geochem. Explor. 2018, 194, 19-28. [CrossRef]

22. Sarangi, S.; Mohanty, S.P.; Barik, A. Rare earth element characteristics of Paleoproterozoic cap carbonates pertaining to the Sausar Group, Central India: Implications for ocean paleoredox conditions. J. Asian Earth Sci. 2017, 148, 31-50. [CrossRef]

23. Özyurt, M.; Kirmaci, M.Z.; Yilmaz, İ.Ö.; Kandemir, R. Sedimentological and Geochemical Records of Lower Cretaceous Carbonate Successions Around Trabzon (NE Turkey). In Patterns and Mechanisms of Climate, Paleoclimate and Paleoenvironmental Changes from Low-Latitude Regions; Zhang, Z., Khélif, N., Mezghani, A., Heggy, E., Eds.; Springer: London, UK; Berlin/Heidelberg, Germany, 2019; pp. 19-21.

24. Görür, N. Timing of opening of the Black Sea basin. Tectonophysics 1988, 147, 247-262. [CrossRef]

25. Eren, M.; Tasli, K. Kilop cretaceous hardground (Kale, Gümüshane, NE Turkey): Description and origin. J. Asian Earth Sci. 2002, 20, 433-448. [CrossRef]

26. Kara-Gülbay, R.; Kırmac1, M.Z.; Korkmaz, S. Organic geochemistry and depositional environment of the Aptian bituminous limestone in the Kale Gümüşhane area (NE-Turkey): An example of lacustrine deposits on the platform carbonate sequence. Org. Geochem. 2012, 49, 6-17. [CrossRef] 
27. Kırmac1, M.Z. Sedimatological Investigation of the Upper Jurassic-Lower Cretaceous Berdiga Limestone in the Alucra-Gumushane-Bayburt areas (Eastern Pontide Southern Zone). Ph.D. Thesis, Karadeniz Technical University, Ortahisar/Trabzon, Turkey, 1992; p. 256.

28. Kirmaci, M.Z.; Koch, R.; Bucur, J.I. An Early Cretaceous section in the Kircaova Area (Berdiga Limestone, NE-Turkey) and its correlation with platform carbonates in W-Slovenia. Facies 1996, 34, 1-21. [CrossRef]

29. Koch, R.; Bucur, I.I.; Kirmaci, M.Z.; Eren, M.; Tasli, K. Upper Jurassic and Lower Cretaceous carbonate rocks of the Berdiga Limestone-Sedimentation on an onbound platform with volcanic and episodic siliciclastic influx. Biostratigraphy, facies and diagenesis (Kircaova, Kale-Gümüşhane area; NE-Turkey). Neues Jahrb. Für Geol. Paläontol. Abh. 2008, 247, 23-61. [CrossRef]

30. Vincent, S.J.; Guo, L.; Flecker, R.; BouDagher-Fadel, M.K.; Ellam, R.M.; Kandemir, R. Age constraints on intra-formational unconformities in Upper Jurassic-Lower Cretaceous carbonates in northeast Turkey; geodynamic and hydrocarbon implications. Mar. Petrol. Geol. 2018, 91, 639-657. [CrossRef]

31. Özyurt, M. Origin of Dolomitization in Upper Jurassıc-Lower Cretaceous Platform Carbonates (Berdiga Formatıon) in Gümüşhane Area. Ph.D. Thesis, Karadeniz Technical University, Trabzon, Turkey, 2019.

32. Özyurt, M.; Kırmac1, M.Z.; Al-Aasm, I.S. Geochemical characteristics of Upper Jurassic-Lower Cretaceous platform carbonates in Hazine Mağara, Gümüşhane (northeast Turkey): Implications for dolomitization and recrystallization. Can. J. Earth Sci. 2019, 56, 306-320. [CrossRef]

33. Özyurt, M.; Al-Aasm, İ; Kirmaci, M.Z. Diagenetic Evolution of Upper Jurassic-Lower Cretaceous Berdiga Formation, NE Turkey: Petrographic and Geochemical Evidence. In Paleobiodiversity and Tectono-Sedimentary Records in the Mediterranean Tethys and Related Eastern Areas; Boughdiri, M., Bádenas, B., Selden, P., Jaillard, E., Bengtson, P., Granier, B.R.C., Eds.; Springer: London, UK; Berlin/Heidelberg, Germany,, 2019; pp. 175-177.

34. Kırmacı, M.Z.; Yıldız, M.; Kandemir, R.; Eroğlu-Gümrük, T. Multistage dolomitization in Late Jurassic-Early Cretaceous platform carbonates (Berdiga Formation), Başoba Yayla (Trabzon), NE Turkey: Implications of the generation of magmatic arc on dolomitization. Mar. Petrol. Geol. 2018, 89, 515-529. [CrossRef]

35. Pelin, S. Geological Investigation of Alucra (Giresun) Southeast Region in Terms of Petroleum Opportunities. Ph.D. Thesis, Karadeniz Technical University, Trabzon, Turkey, 1977.

36. Tasl1, K. Stratigraphy, Paleogeography and Micropaleontology of Upper Jurassic-Lower Cretaceous Carbonate Sequence in the Gümüshane and Bayburt Areas (NE Turkey). Ph.D. Thesis, Karadeniz Technical University, Trabzon, Turkey, 1991.

37. Taslı, K.; Özer, E.; Yılmaz, C. Biostratigraphic and Environmental Analysis of the Upper Jurassic-Lower Cretaceous Carbonate Sequence in the Başoba Yayla Area (Trabzon, NE Turkey). Turk. J. Earth Sci. 2000, 8, 125-135.

38. Yildiz, M.; Ziya Kirmaci, M.; Kandemir, R.; Taslı, K. Benthic Foraminiferal Assemblages and Facies Analysis of the Late Jurrasic-Early Cretaceous Platform Carbonate Succession in the Mescitli-İkisu Area (Gümüşhane, NE Turkey). In Proceedings of the ICOCEE-CAPPADOCIA2017 Conference, Nevsehir, Turkey, 8-10 May 2017.

39. Yildiz, M.; Ziya Kirmaci, M.; Kandemir, R. Dolomitization in Late Jurassic-Early Cretaceous Platform Carbonates (Berdiga Formation), Ayralaksa Yayla (Trabzon), NE Turkey. In Proceedings of the 19th EGU General Assembly, Vienna, Austria, 23-28 April 2017; Volume 19, p. 11661.

40. Okay, A.I.; Sahinturk, O. AAPG Memoir 68: Regional and Petroleum Geology of the Black Sea and Surrounding Region. Chapter 15. Geol. East. Pontides 1997, 291-311.

41. Okay, A.I.; Tüysüz, O. Tethyan Sutures of Northern Turkey; Geological Society Special Publications: London, UK, 1999; Volume 156, pp. 475-515.

42. Gedikoğlu, A.; Pelin, S.; Özsayar, T. The main lines of geotectonic development of East Pontids in the Mesozoic era: Geocome-I. Min. Res. Exp. Inst. Geol. Soc. Turk. 1979, 551-581.

43. Aydin, F. Geochronology, geochemistry, and petrogenesis of the Maçka subvolcanic intrusions: Implications for the Late Cretaceous magmatic and geodynamic evolution of the eastern part of the Sakarya Zone, northeastern Turkey. Int. Geol. Rev. 2014, 56, 1246-1275. [CrossRef]

44. Karsli, O.; Dokuz, A.; Uysal, İ; Aydin, F.; Kandemir, R.; Wijbrans, J. Generation of the Early Cenozoic adakitic volcanism by partial melting of mafic lower crust, Eastern Turkey: Implications for crustal thickening to delamination. Lithos 2010, 114, 109-120. [CrossRef] 
45. Karsli, O.; Dokuz, A.; Uysal, I.; Aydin, F.; Chen, B.; Kandemir, R.; Wijbrans, J. Relative contributions of crust and mantle to generation of Campanian high-K calc-alkaline I-type granitoids in a subduction setting, with special reference to the Harşit Pluton, Eastern Turkey. Contrib. Mineral. Petrol. 2010, 160, 467-487. [CrossRef]

46. Karsli, O.; Ketenci, M.; Uysal, İ.; Dokuz, A.; Aydin, F.; Chen, B.; Wijbrans, J. Adakite-like granitoid porphyries in the Eastern Pontides, NE Turkey: Potential parental melts and geodynamic implications. Lithos 2011, 127, 354-372. [CrossRef]

47. Yücel, C.; Arslan, M.; Temizel, I.; Yazar, E.A.; Ruffet, G. Evolution of K-rich magmas derived from a net veined lithospheric mantle in an ongoing extensional setting: Geochronology and geochemistry of Eocene and Miocene volcanic rocks from Eastern Pontides (Turkey). Gondwana Res. 2017, 45, 65-86. [CrossRef]

48. Yücel, C. Geochronology, geochemistry, and petrology of adakitic Pliocene-Quaternary volcanism in the Şebinkarahisar (Giresun) area, NE Turkey. Int. Geol. Rev. 2019, 61, 754-777. [CrossRef]

49. Delibaş, O.; Moritz, R.; Ulianov, A.; Chiaradia, M.; Saraç, C.; Revan, K.M.; Göç, D. Cretaceous subduction-related magmatism and associated porphyry-type $\mathrm{Cu}-\mathrm{Mo}$ prospects in the Eastern Pontides, Turkey: New constraints from geochronology and geochemistry. Lithos 2016, 248, 119-137. [CrossRef]

50. Yilmaz, C.; Carannante, G.; Kandemir, R. The rift-related Late Cretaceous drowning of the Gümüshane carbonate platform (NE Turkey). Boll. Della Soc. Geol. Italiana 2008, 127, 37-50.

51. Özyurt, M.; Kırmac1, M.Z.; Yılmaz, İ.Ö.; Kandemir, R.; Taslı, K. Sedimentological and geochemical approaches for determination of the paleooceanographic and paleoclimatic conditions of Lower Cretaceous marine deposits of the eastern part of Sakarya Zone, NE Turkey. Int. J. Earth Sci.. Under review.

52. Kırmac1, M.Z.; Akdağ, K. Origin of dolomite in the Late Cretaceous-Paleocene limestone turbidites, eastern Pontides, Turkey. Sediment. Geol. 2005, 181, 39-57. [CrossRef]

53. Yılmaz, C. Gümüşhane-Bayburt yöresindeki mesozoyik havzalarının tektono-sedimantolojik kayıtları ve kontrol etkenleri. Türk. Jeol. Bül. 2002, 45, 141-164.

54. Güven, İ. 1/100000 Ölçekli Açınsama Nitelikli Türkiye Jeoloji Haritaları, Trabzon-C28 ve D28 Paftaları; Jeoloji Etütleri Dairesi, MTA Genel Müdürlüğü: Ankara, Turkey, 1998.

55. Topuz, G.; Altherr, R.; Schwarz, W.H.; Dokuz, A.; Meyer, H.P. Variscan amphibolite-facies rocks from the Kurtoğlu metamorphic complex (Gümüşhane area, Eastern Pontides, Turkey). Int. J. Earth Sci. 2007, 96, 861. [CrossRef]

56. Dokuz, A. A slab detachment and delamination model for the generation of Carboniferous high-potassium I-type magmatism in the Eastern Pontides, NE Turkey: The Köse composite pluton. Gondwana Res. 2011, 19, 926-944. [CrossRef]

57. Topuz, G.; Altherr, R.; Siebel, W.; Schwarz, W.H.; Zack, T.; Hasözbek, A.; Şen, C. Carboniferous high-potassium I-type granitoid magmatism in the Eastern Pontides: The Gümüşhane pluton (NE Turkey). Lithos 2010, 116, 92-110. [CrossRef]

58. Kandemir, R. Sedimentary Characteristics and Depositional Conditions of Lower-Middle Jurassic Şenköy Formation in and Around Gümüşhane. Ph.D. Thesis, Karadeniz Technical University, Trabzon, Turkey, 2004, unpublished work.

59. Kandemir, R.; Yilmaz, C. Lithostratigraphy, facies, and deposition environment of the lower Jurassic Ammonitico Rosso type sediments (ARTS) in the Gümüşhane area, NE Turkey: Implications for the opening of the northern branch of the Neo-Tethys Ocean. J. Asian Earth Sci. 2009, 34, 586-598. [CrossRef]

60. Eyuboglu, Y. Petrogenesis and U-Pb zircon chronology of felsic tuffs interbedded with turbidites (Eastern Pontides Orogenic Belt, NE Turkey): Implications for Mesozoic geodynamic evolution of the eastern Mediterranean region and accumulation rates of turbidite sequences. Lithos 2015, 212, 74-92.

61. Yilmaz, C.; Kandemir, R. Sedimentary records of the extensional tectonic regime with temporal cessation: Gumushane Mesozoic Basin (NE Turkey). Geol. Carpath. Bratisl. 2006, 57, 3.

62. Arslan, M.; Aliyazicioglu, I. Geochemical and petrological characteristics of the Kale (Gümüshane) volcanic rocks: Implications for the Eocene evolution of eastern Pontide arc volcanism, northeast Turkey. Int. Geol. Rev. 2001, 43, 595-610. [CrossRef]

63. Karsli, O.; Chen, B.; Aydin, F.; Şen, C. Geochemical and Sr-Nd-Pb isotopic compositions of the Eocene Dölek and Sariçiçek Plutons, Eastern Turkey: Implications for magma interaction in the genesis of high-K calc-alkaline granitoids in a post-collision extensional setting. Lithos 2007, 98, 67-96. [CrossRef] 
64. Li, Y.; Zhao, L.; Chen, Z.Q.; Algeo, T.J.; Cao, L.; Wang, X. Oceanic environmental changes on a shallow carbonate platform (Yangou, Jiangxi Province, South China) during the Permian-Triassic transition: Evidence from rare earth elements in conodont bioapatite. Palaeogeogr. Palaeoclimatol. Palaeoecol. 2017, 486, 6-16. [CrossRef]

65. Premoli Silva, I.; Sliter, W.V. Cretaceous planktonic foraminiferal biostratigraphy and evolutionary trends from the Bottaccione section, Gubbio, Italy. Paleontogr. Ital. 1995, 82, 1-89.

66. Dunham, R.J. Classification of Carbonate Rocks According to Depositional Textures; AAPG: Tulsa, OK, USA, 1962; pp. 108-121.

67. Flügel, E. Microfacies Data: Fabrics. In Microfacies of Carbonate Rocks; Springer: Berlin/Heidelberg, Germany, 2004; pp. 177-242.

68. McLennan, S.M.; Taylor, S.R. Archaean Sedimentary Rocks and Their Relation to the Composition of the Archaean Continental Crust. In Archaean Geochemistry; Springer: Berlin/Heidelberg, Germany, 1984; pp. 47-72.

69. Bau, M.; Dulski, P. Distribution of yttrium and rare-earth elements in the Penge and Kuruman iron-formations, Transvaal Supergroup, South Africa. Precambrian Res. 1996, 79, 37-55. [CrossRef]

70. Shields, G.; Stille, P. Diagenetic constraints on the use of cerium anomalies as palaeoseawater redox proxies: An isotopic and REE study of Cambrian phosphorites. Chem. Geol. 2001, 175, 29-48. [CrossRef]

71. Alexander, B.W.; Bau, M.; Andersson, P.; Dulski, P. Continentally-derived solutes in shallow Archean seawater: Rare earth element and Nd isotope evidence in iron formation from the 2.9 Ga Pongola Supergroup, South Africa. Geochim. Et Cosmochim. Acta 2008, 72, 378-394. [CrossRef]

72. Tang, Y.; Han, G.; Wu, Q.; Xu, Z. Use of rare earth element patterns to trace the provenance of the atmospheric dust near Beijing, China. Environ. Earth Sci. 2013, 68, 871-879. [CrossRef]

73. Elderfield, H.; Upstill-Goddard, R.; Sholkovitz, E.R. The rare earth elements in rivers, estuaries and coastal sea waters: Processes affecting crustal input of elements to the ocean and their significance to the composition of sea water. Geochim. Cosmocim. Acta 1990, 55, 1807-1813.

74. Hu, M.; Ngia, N.R.; Gao, D. Dolomitization and hydrotectonic model of burial dolomitization of the Furongian-Lower Ordovician carbonates in the Tazhong Uplift, central Tarim Basin, NW China: Implications from petrography and geochemistry. Mar. Petrol. Geol. 2019, 106, 88-115. [CrossRef]

75. Zaky, A.H.; Brand, U.; Azmy, K. A new sample processing protocol for procuring seawater REE signatures in biogenic and abiogenic carbonates. Chem. Geol. 2015, 416, 36-50. [CrossRef]

76. Gromet, L.P.; Haskin, L.A.; Korotev, R.L.; Dymek, R.F. The "North American shale composite": Its compilation, major and trace element characteristics. Geochim. Et Cosmochim. Acta 1984, 48, 2469-2482. [CrossRef]

77. Bau, M. Rare-earth element mobility during hydrothermal and metamorphic fluid-rock interaction and the significance of the oxidation state of europium. Chem. Geol. 1991, 93, 219-230. [CrossRef]

78. Liu, J.; Song, J.; Yuan, H.; Li, X.; Li, N.; Duan, L. Rare earth element and yttrium geochemistry in sinking particles and sediments of the Jiaozhou Bay, North China: Potential proxy assessment for sediment resuspension. Mar. Pollut. Bull. 2019, 144, 79-91. [CrossRef] [PubMed]

79. Nozaki, Y.; Zhang, J.; Amakawa, H. The fractionation between $\mathrm{Y}$ and Ho in the marine environment. Earth Planet. Sci. Lett. 1997, 148, 329-340. [CrossRef]

80. Bau, M. Controls on the fractionation of isovalent trace elements in magmatic and aqueous systems: Evidence from $\mathrm{Y} / \mathrm{Ho}, \mathrm{Zr} / \mathrm{Hf}$, and lanthanide tetrad effect. Contrib. Mineral. Petrol. 1996, 123, 323-333. [CrossRef]

81. Banner, J.L.; Hanson, G.N. Calculation of simultaneous isotopic and trace element variations during water-rock interaction with applications to carbonate diagenesis. Geochim. Et Cosmochim. Acta 1990, 54, 3123-3137. [CrossRef]

82. Banner, J.L.; Hanson, G.N.; Meyers, W.J. Rare earth element and Nd isotopic variations in regionally extensive dolomites from the Burlington-Keokuk Formation (Mississippian); implications for REE mobility during carbonate diagenesis. J. Sediment. Res. 1988, 58, 415-432.

83. Barrat, J.A.; Boulegue, J.; Tiercelin, J.J.; Lesourd, M. Strontium isotopes and rare-earth element geochemistry of hydrothermal carbonate deposits from Lake Tanganyika, East Africa. Geochim. Et Cosmochim. Acta 2000, 64, 287-298. [CrossRef]

84. Bau, M. Scavenging of dissolved yttrium and rare earths by precipitating iron oxyhydroxide: Experimental evidence for Ce oxidation, Y-Ho fractionation, and lanthanide tetrad effect. Geochim. Et Cosmochim. Acta 1999, 63, 67-77. [CrossRef] 
85. Li, F.; Yan, J.; Burne, R.V.; Chen, Z.Q.; Algeo, T.J.; Zhang, W.; Xie, S. Paleo-seawater REE compositions and microbial signatures preserved in laminae of Lower Triassic ooids. Palaeogeogr. Palaeoclimatol. Palaeoecol. 2017, 486, 96-107. [CrossRef]

86. Zhao, M.Y.; Zheng, Y.F. A geochemical framework for retrieving the linked depositional and diagenetic histories of marine carbonates. Earth Planet. Sci. Lett. 2017, 460, 213-221. [CrossRef]

87. Bau, M.; Alexander, B. Preservation of primary REE patterns without Ce anomaly during dolomitization of Mid-Paleoproterozoic limestone and the potential re-establishment of marine anoxia immediately after the “Great Oxidation Event". S. Afr. J. Geol. 2006, 109, 81-86. [CrossRef]

88. Bau, M.; Balan, S.; Schmidt, K.; Koschinsky, A. Rare earth elements in mussel shells of the Mytilidae family as tracers for hidden and fossil high-temperature hydrothermal systems. Earth Planet. Sci. Lett. 2010, 299, 310-316. [CrossRef]

89. Kamber, B.S.; Webb, G.E. The geochemistry of late Archaean microbial carbonate: Implications for ocean chemistry and continental erosion history. Geochim. Et Cosmochim. Acta 2001, 65, 2509-2525. [CrossRef]

90. Tanaka, K.; Kawabe, I. REE abundances in ancient seawater inferred from marine limestone and experimental REE partition coefficients between calcite and aqueous solution. Geochem. J. 2006, 40, 425-435. [CrossRef]

91. Shields, G.A.; Webb, G.E. Has the REE composition of seawater changed over geological time? Chem. Geol. 2004, 204, 103-107. [CrossRef]

92. Bolhar, R.; Van Kranendonk, M.J. A non-marine depositional setting for the northern Fortescue Group, Pilbara Craton, inferred from trace element geochemistry of stromatolitic carbonates. Precambrian Res. 2007, 155, 229-250. [CrossRef]

93. Bolhar, R.; Kamber, B.S.; Moorbath, S.; Fedo, C.M.; Whitehouse, M.J. Characterisation of early Archaean chemical sediments by trace element signatures. Earth Planet. Sci. Lett. 2004, 222, 43-60. [CrossRef]

94. MacLeod, K.G.; Irving, A.J. Correlation of cerium anomalies with indicators of paleoenvironment. J. Sediment. Res. 1996, 66, 948-955.

95. Smrzka, D.; Zwicker, J.; Bach, W.; Feng, D.; Himmler, T.; Chen, D.; Peckmann, J. The behavior of trace elements in seawater, sedimentary pore water, and their incorporation into carbonate minerals: A review. Facies 2019, 65, 41. [CrossRef]

96. Zhong, S.; Mucci, A. Partitioning of rare earth elements (REEs) between calcite and seawater solutions at $25 \mathrm{C}$ and $1 \mathrm{~atm}$, and high dissolved REE concentrations. Geochim. Et Cosmochim. Acta 1995, 59, 443-453. [CrossRef]

97. Feng, D.; Chen, D.; Peckmann, J. Rare earth elements in seep carbonates as tracers of variable redox conditions at ancient hydrocarbon seeps. Terra Nova 2009, 21, 49-56. [CrossRef]

98. Zhu, B.; Ge, L.; Yang, T.; Jiang, S.; Lv, X. Stable isotopes and rare earth element compositions of ancient cold seep carbonates from Enza River, northern Apennines (Italy): Implications for fluids sources and carbonate chimney growth. Mar. Petrol. Geol. 2019, 109, 434-448. [CrossRef]

99. Auer, G.; Reuter, M.; Hauzenberger, C.A.; Piller, W.E. The impact of transport processes on rare earth element patterns in marine authigenic and biogenic phosphates. Geochim. Et Cosmochim. Acta 2017, 203, 140-156. [CrossRef]

100. Kato, Y.; Yamaguchi, K.E.; Ohmoto, H. Rare earth elements in Precambrian banded iron formations: Secular changes ofCe andEu anomalies and evolution of atmospheric oxygen. Evol. Early Earth Atmos. Hydros. Biosph. Constraints Ore Depos. 2006, 198, 269.

101. Tostevin, R.; Shields, G.A.; Tarbuck, G.M.; He, T.; Clarkson, M.O.; Wood, R.A. Effective use of cerium anomalies as a redox proxy in carbonate-dominated marine settings. Chemical Geology 2016, 438, 146-162. [CrossRef]

102. Lawrence, M.G.; Jupiter, S.D.; Kamber, B.S. Aquatic geochemistry of the rare earth elements and yttrium in the Pioneer River catchment, Australia. Mar. Freshw. Res. 2006, 57, 725-736. [CrossRef]

103. Parsapoor, A.; Khalili, M.; Mackizadeh, M.A. The behaviour of trace and rare earth elements (REE) during hydrothermal alteration in the Rangan area (Central Iran). J. Asian Earth Sci. 2009, 34, 123-134. [CrossRef]

104. Klinkhammer, G.P.; Elderfield, H.; Edmond, J.M.; Mitra, A. Geochemical implications of rare earth element patterns in hydrothermal fluids from mid-ocean ridges. Geochim. Et Cosmochim. Acta 1994, 58, 5105-5113. [CrossRef]

105. Morse, J.W.; Mackenzie, F.T. Geochemistry of Sedimentary Carbonates; Elsevier: Amsterdam, The Netherland, 1990. 
106. Mresah, M.H. The massive dolomitization of platformal and basinal sequences: Proposed models from the Paleocene, Northeast Sirte Basin, Libya. Sediment. Geol. 1998, 116, 199-226. [CrossRef]

107. Bischoff, J.L.; Fyfe, W.S. Catalysis, inhibition, and the calcite-aragonite problem; [Part] 1, The aragonite-calcite transformation. Am. J. Sci. 1968, 266, 65-79. [CrossRef]

108. McManus, K.M. The Aqueous Aragonite to Calcite Transformation: Rate, Mechanisms, and Its Role in the Development of Neomorphic Fabrics. PhD Thesis, Virginia Polytechnic Institute and State University, Blacksburg, VA, USA, 1982.

109. Perdikouri, C.; Piazolo, S.; Kasioptas, A.; Schmidt, B.C.; Putnis, A. Hydrothermal replacement of aragonite by calcite: Interplay between replacement, fracturing and growth. Eur. J. Mineral. 2013, 25, 123-136. [CrossRef]

110. Hashim, M.S.; Kaczmarek, S.E. Experimental stabilization of carbonate sediments to calcite: Insights into the depositional and diagenetic controls on calcite microcrystal texture. Earth Planet. Sci. Lett. 2020, 538, 116235. [CrossRef]

111. Moshier, S.O. Microporosity in micritic limestones: A review. Sediment. Geol. 1989, 63, 191-213. [CrossRef]

112. Lambert, L.; Durlet, C.; Loreau, J.P.; Marnier, G. Burial dissolution of micrite in Middle East carbonate reservoirs (Jurassic-Cretaceous): Keys for recognition and timing. Mar. Petrol. Geol. 2006, 23, 79-92. [CrossRef]

113. Loucks, R.G.; Lucia, F.J.; Waite, L.E. Origin and description of the micropore network within the Lower Cretaceous Stuart City Trend tight-gas limestone reservoir in Pawnee Field in South Texas. GCAGS J. 2013, 2, $29-41$.

114. Karsli, O.; İlhan, M.; Kandemir, R.; Dokuz, A.; Duygu, L. In Review. Nature of the Early Cretaceous calk-alkaline lamprophyre and high-Nb alkaline basaltic dykes in Sakarya Zone, NE Turkey: Constrains on their linkage to subduction initiation of Neotethyan oceanic Slab. Contrib. Mineral. Petrol.. Under review.

115. Reynard, B.; Lécuyer, C.; Grandjean, P. Crystal-chemical controls on rare-earth element concentrations in fossil biogenic apatites and implications for paleoenvironmental reconstructions. Chem. Geol. 1999, 155, 233-241. [CrossRef]

116. Michard, A.; Albarède, F. The REE content of some hydrothermal fluids. Chem. Geol. 1986, 55, 51-60. [CrossRef]

117. Olivarez, A.M.; Owen, R.M. REE/Fe variations in hydrothermal sediments: Implications for the REE content of seawater. Geochim. Et Cosmochim. Acta 1989, 53, 757-762. [CrossRef]

118. Bright, C.A.; Cruse, A.M.; Lyons, T.W.; MacLeod, K.G.; Glascock, M.D.; Ethington, R.L. Seawater rare-earth element patterns preserved in apatite of Pennsylvanian conodonts? Geochim. Et Cosmochim. Acta 2009, 73, 1609-1624. [CrossRef]

119. German, C.R.; Elderfield, H. Rare earth elements in Saanich Inlet, British Columbia, a seasonally anoxic basin. Geochim. Et Cosmochim. Acta 1989, 53, 2561-2571. [CrossRef]

120. Koeppenkastrop, D.; Eric, H. Sorption of rare-earth elements from seawater onto synthetic mineral particles: An experimental approach. Chem. Geol. 1992, 95, 251-263. [CrossRef]

121. Derry, L.A.; Jacobsen, S.B. The chemical evolution of Precambrian seawater: Evidence from REEs in banded iron formations. Geochim. Et Cosmochim. Acta 1990, 54, 2965-2977. [CrossRef]

122. Jenkyns, H.C. Transient cooling episodes during Cretaceous Oceanic Anoxic Events with special reference to OAE 1a (Early Aptian). Philos. Trans. Royal Soc. A Math. Phys. Eng. Sci. 2018, 376, 20170073. [CrossRef]

123. Tasl1, K.; Özsayar, T. Stratigraphy and paleoenvironmental setting of the Albian-Campanian deposits within the Gümüsßhane province (Eastern Pontides, NE Turkey). Turk. Assoc. Petrol. Geol. Bull. 1997, 9, 13-29.

(C) 2020 by the authors. Licensee MDPI, Basel, Switzerland. This article is an open access article distributed under the terms and conditions of the Creative Commons Attribution (CC BY) license (http://creativecommons.org/licenses/by/4.0/). 